\title{
Electroreduction of Iron(III) Oxide Pellets to Iron in Alkaline Media: A Typical Shrinking-Core Reaction Process
}

\author{
XINGLI ZOU, SHANLIN GU, XIONGGANG LU, XUELIANG XIE, CHANGYUAN LU, \\ ZHONGFU ZHOU, and WEIZHONG DING
}

Low temperature electrochemical reduction of iron(III) oxide to iron in a strongly alkaline solution has been systematically investigated in this article. The facile electrochemical process was carried out in 50 to 70 wt pct aqueous $\mathrm{NaOH}$ solution at $383 \mathrm{~K}\left(110^{\circ} \mathrm{C}\right)$ and $1.7 \mathrm{~V}$. The preformed spherical $\mathrm{Fe}_{2} \mathrm{O}_{3}$ pellets with porous structures were used directly as precursors for the electrolytic production of iron. The influences of the experimental parameters on the electroreduction process and the characteristics of the iron products as well as the reaction mechanisms were investigated. The results show that the precursor's pre-sintering process and the concentration of $\mathrm{NaOH}$ aqueous electrolyte have significant influences on the electroreduction process. The electroreduction-generated spherical metallic iron layer comprising dendritic iron crystals is first formed on the surface of $\mathrm{Fe}_{2} \mathrm{O}_{3}$ pellet precursor and then extends gradually into the pellet's interior along the radial direction. The electroreduction process is confirmed to be a typical shrinking-core reaction process. The direct solid state electroreduction mechanism and the dissolution-electrodeposition mechanism coexist in the electrochemical process. The experimental observations suggest that the dissolution-electrodeposition mechanism appears to be the dominant mechanism under the experimental conditions employed in this study. This facile process may open a new green electricitybased route for the production of dendritic iron crystals from iron(III) oxide in alkaline media.

DOI: $10.1007 / \mathrm{s} 11663-015-0336-8$

(C) The Minerals, Metals \& Materials Society and ASM International 2015

\section{INTRODUCTION}

THE carbothermal reduction of iron is one of the founding technological pillars of human civilization. ${ }^{[1,2]}$ Nowadays or even in the future, iron metal/iron-based alloys will still represent as the most widely used structural materials. ${ }^{[3,4]}$ Currently, iron metal is commonly produced through the $\mathrm{CO}_{2}$ intensive reduction of iron oxides by carbon-coke in blast furnace. The current carbothermic-based process faces difficult environmental challenges, with large amount of $\mathrm{CO}_{2}$ emitted during the production of steel every year. ${ }^{[4]}$ Therefore, in recent years, the environmentally friendly processes, such as the electrochemical processes have been widely investigated as potential green routes for the production of iron and iron-base alloys. ${ }^{[5-19]}$ The ultra-low $\mathrm{CO}_{2}$ steelmaking (ULCOS) program was set up in Europe with the aim of developing new technologies to reduce greenhouse gases emissions in iron production. ${ }^{[15,16]}$

XINGLI ZOU, Lecturer, SHANLIN GU, Master Candidate, XIONGGANG LU and WEIZHONG DING, Professors, XUELIANG XIE and CHANGYUAN LU, Ph.D. Candidates, are with the Shanghai Key Laboratory of Modern Metallurgy and Materials Processing, Shanghai University, Shanghai 200072, P.R. China. Contact e-mails: xinglizou@shu.edu.cn; luxg@shu.edu.cn ZHONGFU ZHOU, Professor, is with the Shanghai Key Laboratory of Modern Metallurgy and Materials Processing, Shanghai University and also Lecturer with the Institute of Mathematics and Physics, Aberystwyth University, Aberystwyth SY23 3BZ, U.K.

Manuscript submitted December 3, 2014.

Article published online April 8, 2015
Electrolytic production of iron is expected to be capable of sustaining a reasonably low-carbon emission as demonstrated in aqueous solutions and molten salts. $^{[1-7,10-18]}$ Although electrochemical extraction of aluminum has achieved great success due to the electrodeposition process occurs. However, it still remains a challenge to extend the electrodeposition process to iron-based materials production since it requires dissolved raw materials and liquid metallic product. ${ }^{[4]}$ Molten oxide electrolysis (MOE) is an electrometallurgical technique that enables the direct electrolytic production of liquid iron from iron oxides ${ }^{[3,8]}$ However, high temperature $\left[>1811 \mathrm{~K}\left(1538{ }^{\circ} \mathrm{C}\right)\right]$ is needed inevitably to ensure the metallic iron products maintain in liquid form. Although the electrolytic production of iron powder at low temperature also has its limitations, e.g., iron powder products require melting process for further manufacturing and can possibly encounter oxidation issues. However, searching for new route for lowtemperature electrolytic production of iron metal is still extremely needed due to its environmental friendliness.

The direct electrochemical reduction of metal oxides to metals/alloys in molten salts has been extensively studied for many years due to its low energy consumption. ${ }^{[20-32]}$ Moreover, the gaseous reduction of iron oxides to metal iron by hydrogen gas has also been recognized as an environmental friendly way. ${ }^{[33-36]}$ However, high cost of hydrogen production is still a challenge for iron and steel industry. ${ }^{[34-36]}$ On the contrary, the inherent advantage of the electrochemical process is its environmental 
compatibility since the electron is a "clean/green" reagent. ${ }^{[37-39]}$ Li et al. ${ }^{[17]}$ and Haarberg et al. ${ }^{[40]}$ successively obtained pure iron metal from iron(III) oxide by the direct electroreduction/electrodeposition routes in molten salts at temperature $>1073 \mathrm{~K} \quad\left(800^{\circ} \mathrm{C}\right)$. Cox and Fray ${ }^{[12,13]}$ pioneered their work on the iron production from $\mathrm{Fe}(\mathrm{III})$ oxide by electrochemical reduction at a lower temperature of about $803 \mathrm{~K}\left(530^{\circ} \mathrm{C}\right)$ in molten $\mathrm{NaOH}$. Allanore et al. ${ }^{[16]}$ proved that hematite particles could be electrochemically reduced to iron in $50 \mathrm{wt}$ pet aqueous $\mathrm{NaOH}$ solution at $383 \mathrm{~K}\left(110^{\circ} \mathrm{C}\right)$. Yuan et al. ${ }^{[14]}$ investigated the electrowinning of iron deposits from iron oxides in $50 \mathrm{wt}$ pct aqueous $\mathrm{NaOH}$ solution at $387 \mathrm{~K}\left(114^{\circ} \mathrm{C}\right)$ with a rotating cathode. He et al. ${ }^{[18]}$ electrochemically reduced magnetite films to iron films and investigated the influence of the texture of the magnetite film precursor on the iron film product. These previous work generally suggested that iron oxides could be electrochemically reduced to iron in molten salts/alkaline solutions. However, the detailed macro- and microstructures variations and their corresponding reaction mechanisms during the electroreduction process, especially the detailed reaction pathway in alkaline electrolytes at low temperature, still need more investigation.

This study provides the compelling evidence of electroreduction of spherical $\mathrm{Fe}_{2} \mathrm{O}_{3}$ pellets to iron crystals in a strongly alkaline solution. The influences of the operation parameters on the electroreduction process and the characteristic of the products were investigated. The connections between the experimental parameters and the corresponding morphology transformations at both macro- and microscales were studied. In addition, the typical shrinking-core reaction process and its corresponding reaction mechanisms were determined and discussed.

\section{EXPERIMENTAL}

Figure 1 schematically illustrates the experimental setup used in this study. A polytetrafluoroethylene (PTFE) container $(250 \mathrm{~mL})$ was fabricated and used as the electrolytic cell. About 120 to $150 \mathrm{~mL}$ of aqueous $\mathrm{NaOH}$ solution, which was freshly prepared with distilled water, was introduced into the electrolytic cell and served as the electrolyte for the experiment. The aqueous $\mathrm{NaOH}$ solutions with different concentrations were prepared by dissolving stoichiometric solid $\mathrm{NaOH}$ (AR, Aladdin) in distilled water. Approximately $60 \mathrm{mg} \quad \mathrm{Fe}_{2} \mathrm{O}_{3}$ powder (AR, Sinopharm Chemical Reagent Co., Ltd; particle size is approximately 1 to $5 \mu \mathrm{m}$ ) was isostatically pressed under $20 \mathrm{MPa}$ into a spherical pellet with a diameter of approximately $3.6 \mathrm{~mm}$. The pressed pellets were sintered at $973 \mathrm{~K}$ to $1573 \mathrm{~K}\left(700{ }^{\circ} \mathrm{C}\right.$ to $\left.1300{ }^{\circ} \mathrm{C}\right)$ in air for 2 hours. The pre-sintering process could provide a sufficient mechanical strength for $\mathrm{Fe}_{2} \mathrm{O}_{3}$ pellet precursor. In addition, the sintered pellet typically possesses porous structure, which is beneficial to the subsequent electroreduction process. The sintered $\mathrm{Fe}_{2} \mathrm{O}_{3}$ pellet was wrapped with porous nickel foil and then attached to an electrode wire to form a cathode. The porous nickel foil used in this experiment has uniform structure (porosity: $\sim 95$ pct; pore per inch: 110; area density: $380 \mathrm{~g} / \mathrm{m}^{2}$; pore size: 0.2 to $0.4 \mathrm{~mm}$ ), which thus can be used as the

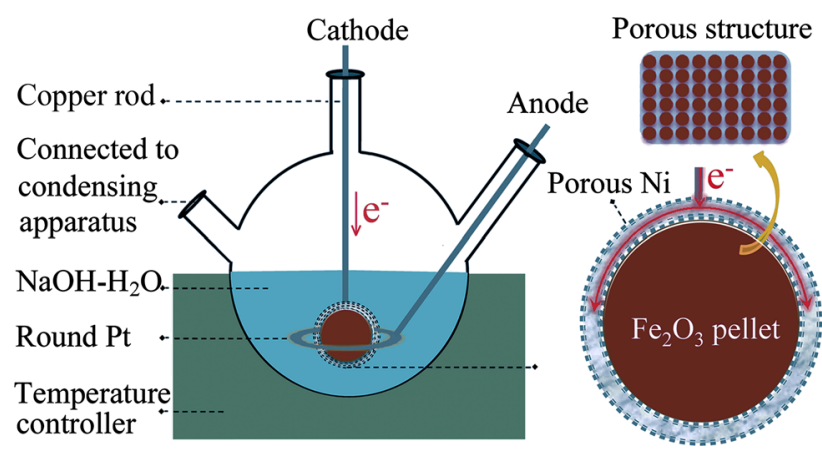

Fig. 1-Schematic illustration of the electroreduction of spherical $\mathrm{Fe}_{2} \mathrm{O}_{3}$ pellet in aqueous $\mathrm{NaOH}$ solution.

extended electronic conductor to provide reasonably uniform electric contact area to the surface of $\mathrm{Fe}_{2} \mathrm{O}_{3}$ pellet. A round platinum wire attached to an electrode wire was served as the anode in the electrolytic cell. The assembled electrolytic cell was placed in a heating mantle. The heating mantle was employed to maintain the temperature of the electrolytic cell at a constant value during the whole electrochemical reduction process. In addition, in order to ensure the concentration of aqueous $\mathrm{NaOH}$ solution keeps at a reasonably stable level during the electroreduction process, an apparatus for condensing water vapor was also used in the experiment. Moreover, in the dissolution-electrodeposition experiment, a cylindrical polished copper rod with a diameter of approximately $6 \mathrm{~mm}\left(S=0.28 \mathrm{~cm}^{2}\right)$ was used as the deposition substrate to replace the $\mathrm{Fe}_{2} \mathrm{O}_{3}$ pellet cathode used in the electroreduction experiment. $\mathrm{Fe}_{2} \mathrm{O}_{3} / \mathrm{NaFeO}_{2}$ particles were directly dissolved in aqueous $\mathrm{NaOH}$ solution to form the $\mathrm{Fe}_{2} \mathrm{O}_{3} / \mathrm{NaFeO}_{2}$-saturated $\mathrm{NaOH}$ electrolytes. The copper rod substrate and the round platinum wire were served as the cathode and anode in the electrodeposition cell, respectively.

Systematic experiments were carried out in 50 to 70 wt pet aqueous $\mathrm{NaOH}$ solution at $383 \mathrm{~K}\left(110^{\circ} \mathrm{C}\right)$ and $1.7 \mathrm{~V}$. The applied potential $1.7 \mathrm{~V}$ was experimentally confirmed to be suitable for the electroreduction of $\mathrm{Fe}_{2} \mathrm{O}_{3}$ precursor to iron, and $\mathrm{NaOH}$ aqueous electrolyte could keep stable during the electrochemical process. After the temperature reached $383 \mathrm{~K}\left(110^{\circ} \mathrm{C}\right)$, the electroreduction experiment was performed at a constant potential of $1.7 \mathrm{~V}$ between the $\mathrm{Fe}_{2} \mathrm{O}_{3}$ cathode and the platinum anode for appropriate duration. A BioLogic HCP-803 electrochemical workstation was used to record the current-time curve during the electroreduction process. Following the electroreduction process, the cathode pellet was taken out, washed with distilled water and absolute alcohol, and then dried rapidly. In order to investigate the reaction process in detail, the partially electroreduced $\mathrm{Fe}_{2} \mathrm{O}_{3}$ pellets were taken periodically during the electroreduction process. The macroand microstructures of the samples were characterized by using an optical microscope (KEYENCE VHX$1000 \mathrm{C}$ ) and a scanning electron microscope (JEOL JSM-6700F). The cross sections of the electrolyzed pellets were prepared by wet grinding the cross sections of the pellets embedded in epoxy using various grades of silicon carbide paper. The cross sections of the samples 
were examined using scanning electron microscopy (SEM). The local elemental composition of the products was determined by an energy dispersive X-ray spectrometer (EDS) (Oxford INCA EDS system) attached to the SEM. The phase composition of the samples was analyzed by X-ray diffraction (XRD) using a Rigaku D/Max-2550 diffractometer. The X-ray photoelectron spectroscopy (XPS) analysis was performed on a PHI5000C ESCA system (Perkin-Elmer). The concentration of the dissolved iron species in the $\mathrm{Fe}_{3} \mathrm{O}_{4}$-saturated 50 wt pet aqueous $\mathrm{NaOH}$ solution was determined by inductively coupled plasma spectroscopy (ICP, Perkin Elmer PE400).

\section{RESULTS AND DISCUSSION}

\section{A. Influence of the Precursor's Pre-sintering Process on the Electroreduction Process}

In order to obtain a sufficient mechanical strength for the subsequent electroreduction process, the pressed $\mathrm{Fe}_{2} \mathrm{O}_{3}$ pellets were pre-sintered in air. Figure 2(a) shows the photos of the pressed initial pellet and the pellets sintered at different temperatures in air for $2 \mathrm{~h}$. It is obvious that the spherical $\mathrm{Fe}_{2} \mathrm{O}_{3}$ pellets shrink gradually (from diameter of 3.6 to $2.8 \mathrm{~mm}$ ) with the increase of the precursor's sintering temperature to $1573 \mathrm{~K}$ $\left(1300{ }^{\circ} \mathrm{C}\right)$. As a result, the volume and porosity of $\mathrm{Fe}_{2} \mathrm{O}_{3}$ pellets change from approximately $24 \mathrm{~mm}^{3}$ and 45 pct (initial pellet) to $12 \mathrm{~mm}^{3}$ and 15 pct [after being sintered at $1573 \mathrm{~K}\left(1300{ }^{\circ} \mathrm{C}\right)$ ] during the pre-sintering process, respectively, as shown in Figure 2(b). Moreover, the appearance (color) of the sintered pellets also changes gradually, especially, the pellets sintered at $1473 \mathrm{~K}$ and $1573 \mathrm{~K}\left(1200{ }^{\circ} \mathrm{C}\right.$ and $\left.1300^{\circ} \mathrm{C}\right)$ exhibit gray black appearance (Figure 2(a)). A typical SEM image of the sintered $\mathrm{Fe}_{2} \mathrm{O}_{3}$ pellet is inserted in Figure 2(b), which clearly shows that the sintered $\mathrm{Fe}_{2} \mathrm{O}_{3}$ precursor possesses porous structure. Actually, an appropriate porosity of precursor is very important for the electroreduction process. ${ }^{[6,41,42]}$ The electroreduction-generated oxygen ions can diffuse through the electrolyte in the various pores of the pellet precursor before entering the bulk electrolyte. The porous oxide precursor also benefits the formation of porous metal product. ${ }^{[41]}$

When the sintering temperature is higher than $1373 \mathrm{~K}$ $\left(1100{ }^{\circ} \mathrm{C}\right)$, the phase composition of $\mathrm{Fe}_{2} \mathrm{O}_{3}$ pellets precursors transforms gradually during the pre-sintering process, as shown in Figure. 3. As evidenced from Figures 3(a) and (b), it is obvious that $\mathrm{Fe}_{2} \mathrm{O}_{3}$ phase partially converts into amorphous iron suboxides when the sintering temperatures are $1473 \mathrm{~K}$ and $1573 \mathrm{~K}$ $\left(1200{ }^{\circ} \mathrm{C}\right.$ and $1300{ }^{\circ} \mathrm{C}$ ). In contrast, $\mathrm{Fe}_{2} \mathrm{O}_{3}$ phase can keep stable when the sintering temperature is lower than $1373 \mathrm{~K}\left(1100{ }^{\circ} \mathrm{C}\right)$, as shown in Figure 3(a). The pellets sintered at $1473 \mathrm{~K}\left(1200{ }^{\circ} \mathrm{C}\right)$ and $1573 \mathrm{~K}\left(1300{ }^{\circ} \mathrm{C}\right)$ were further characterized using XPS, as shown in Figures 3 (c) and (d). The previous work ${ }^{[43]}$ has intensively investigated $\mathrm{Fe}^{2+}$ and $\mathrm{Fe}^{3+}$ ions in oxide materials using XPS. Based on the previous work ${ }^{[43]}$ and the XPS spectra presented in Figures 3(c) and (d), it is obvious

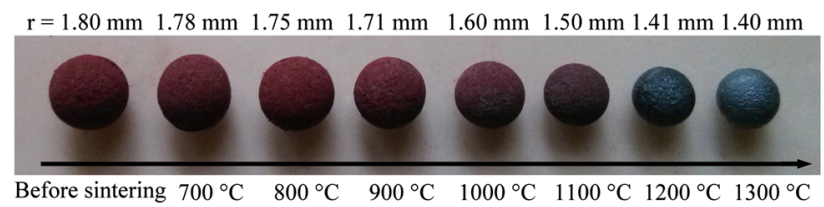

(a)

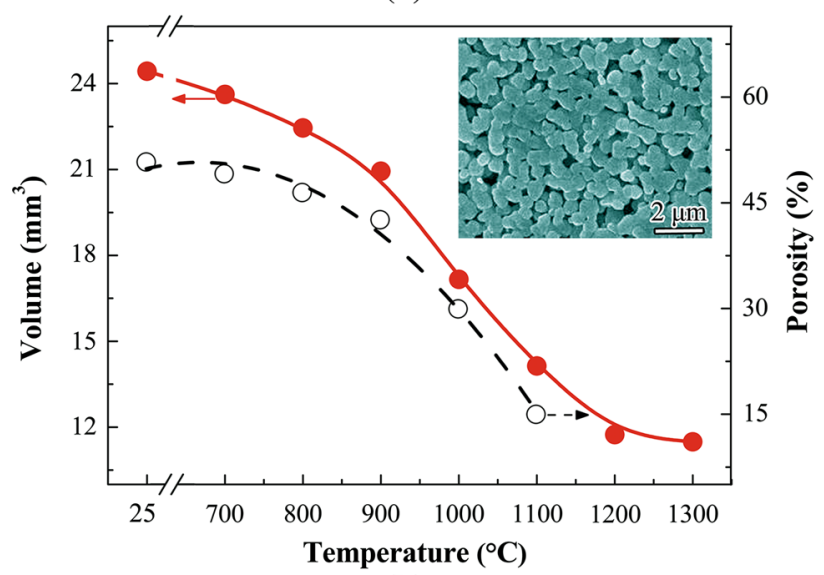

(b)

Fig. 2-(a) Photos of the $\mathrm{Fe}_{2} \mathrm{O}_{3}$ pellets sintered at different temperatures in air for $2 \mathrm{~h},(b)$ variations of the volume and porosity of $\mathrm{Fe}_{2} \mathrm{O}_{3}$ pellets during the pre-sintering process. The inset in $(b)$ is a typical SEM image of the porous structure of the sintered $\mathrm{Fe}_{2} \mathrm{O}_{3}$ pellet.

that the pellets of iron oxides precursors sintered at $1473 \mathrm{~K}$ and $1573 \mathrm{~K}\left(1200{ }^{\circ} \mathrm{C}\right.$ and $\left.1300{ }^{\circ} \mathrm{C}\right)$ contain $\mathrm{Fe}_{2} \mathrm{O}_{3}$ and $\mathrm{Fe}_{3} \mathrm{O}_{4}$ phases, which may be responsible for the different appearances of the sintered pellets (Figure 2(a)). Higher sintering temperature means higher energy cost, therefore, the pressed pellets should be sintered at the appropriate/optimum temperature to guarantee sufficient mechanical strength and appropriate porosity for electroreduction operations.

Figure 4 shows the optical microscopic images, SEM images and the corresponding elemental ( $\mathrm{Fe}$ and $\mathrm{O}$ ) maps of the cross sections of the partially electrolyzed $\mathrm{Fe}_{2} \mathrm{O}_{3}$ pellets. These pellets precursors were sintered at different temperatures firstly, and then electroreduced in 60 wt pet aqueous $\mathrm{NaOH}$ solution at $383 \mathrm{~K}\left(110^{\circ} \mathrm{C}\right)$ and $1.7 \mathrm{~V}$ for 2.5 hours. As evidenced from the figure, the pre-sintering process has significant influence on the electroreduction process. The pellets sintered at higher temperature are more compact than that sintered at lower temperature. The elemental maps clearly show that the oxygen component contained in the precursor has been removed gradually. Relatively uniform spherical porous iron metal layers are generated at the exterior of the iron oxides pellets. The reaction process typically extends from the exterior of the pellet into the pellet's interior along the radial direction. Comparing Figures 4(a) through (f), it can be observed clearly that the electroreduction degree of the pellet sintered at $1373 \mathrm{~K}\left(1100{ }^{\circ} \mathrm{C}\right)$ (Figure $\left.4(\mathrm{~d})\right)$ is more in-depth than that of the pellet sintered under other temperatures. It should be noted that the pellet sintered at $973 \mathrm{~K}\left(700{ }^{\circ} \mathrm{C}\right)$ was broken into pieces during the 


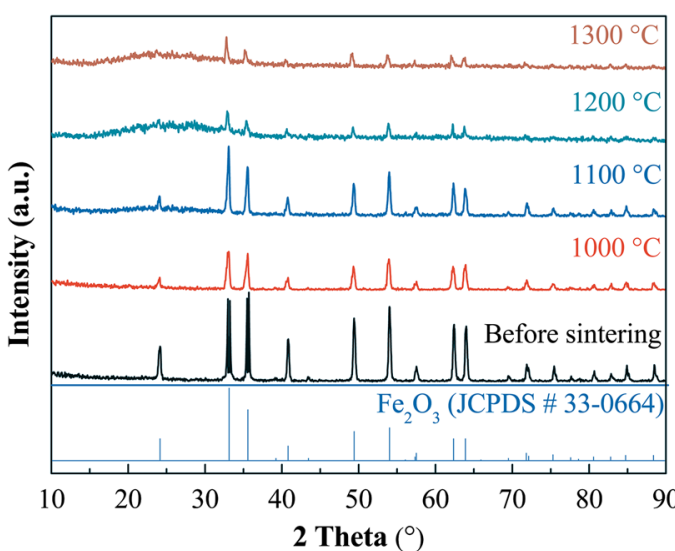

(a)

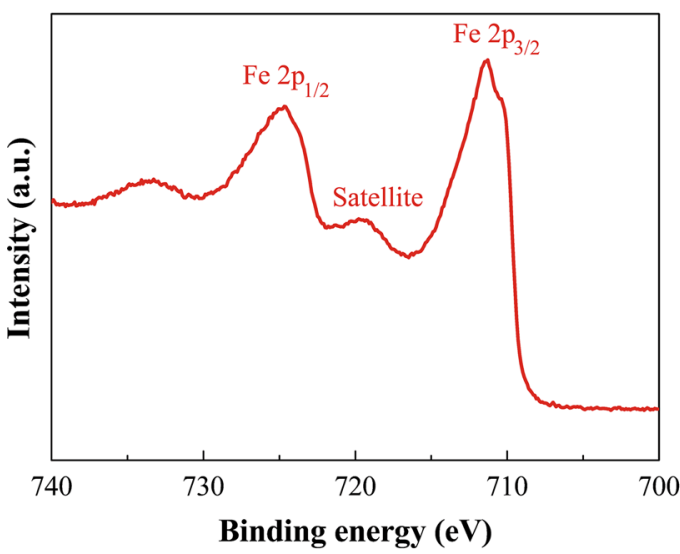

(c)

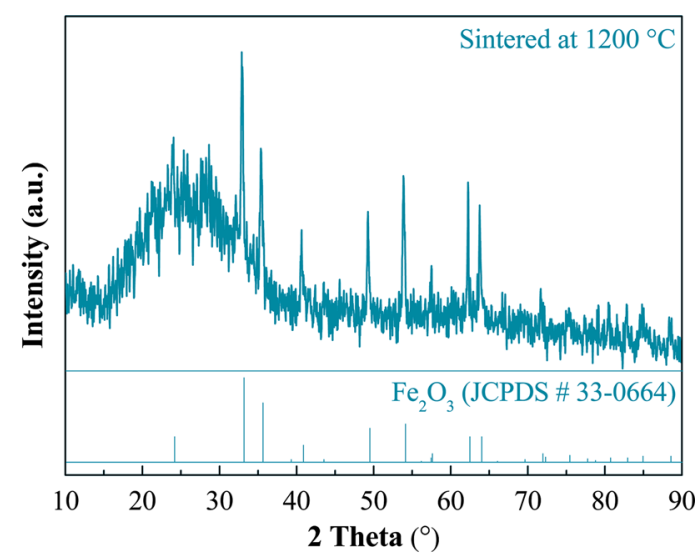

(b)

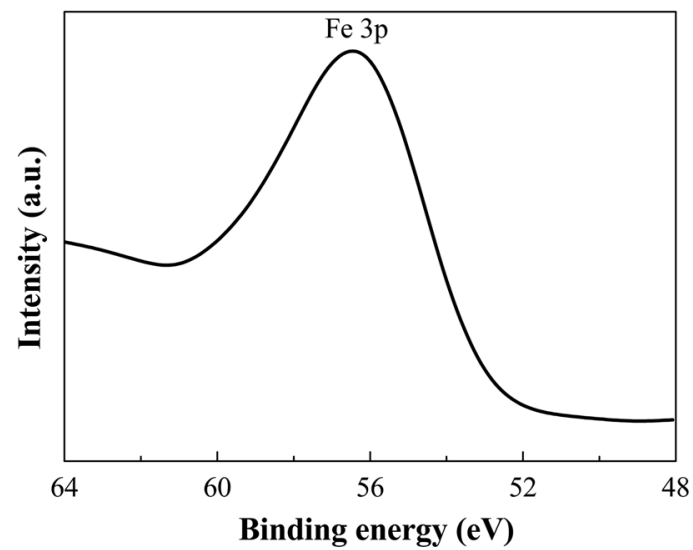

(d)

Fig. 3- (a) XRD patterns of the $\mathrm{Fe}_{2} \mathrm{O}_{3}$ pellets sintered at different temperatures in air for $2 \mathrm{~h}$, (b) details of the XRD pattern of the $\mathrm{Fe} \mathrm{O}_{2} \mathrm{O}_{3}$ pellet sintered at $1473 \mathrm{~K}\left(1200{ }^{\circ} \mathrm{C}\right)$ in air for $2 \mathrm{~h},(c)$ and $(d)$ XPS spectra of $\mathrm{Fe} 2 \mathrm{p}(c)$ and $\mathrm{Fe} 3 \mathrm{p}(d)$ for the $\mathrm{Fe}_{2} \mathrm{O}_{3}$ pellet sintered at $1473 \mathrm{~K}\left(1200{ }^{\circ} \mathrm{C}\right)$ in air for $2 \mathrm{~h}$.

electroreduction process, which means the pellet sintered at $973 \mathrm{~K}\left(700{ }^{\circ} \mathrm{C}\right)$ is not suitable for the electroreduction process. Therefore, the appropriate sintering temperature range for $\mathrm{Fe}_{2} \mathrm{O}_{3}$ pellet precursor is experimentally proven to be $1073 \mathrm{~K}$ to $1373 \mathrm{~K}\left(800{ }^{\circ} \mathrm{C}\right.$ to $\left.1100{ }^{\circ} \mathrm{C}\right)$. However, $1373 \mathrm{~K}\left(1100{ }^{\circ} \mathrm{C}\right)$ is demonstrated to be the optimum temperature for the pre-sintering process based on the present morphology observation (Figure 4).

The current-time curves of the electroreduction of the iron oxides pellets sintered at different temperatures are shown in Figure 5. The electroreduction processes were carried out in 60 wt pet aqueous $\mathrm{NaOH}$ solution at $383 \mathrm{~K}\left(110^{\circ} \mathrm{C}\right)$ and $1.7 \mathrm{~V}$ for 2.5 hours. It can be seen from the figure that the current-time curves exhibit different features. However, the current-time curves recorded during the electroreduction of the $\mathrm{Fe}_{2} \mathrm{O}_{3}$ pellets sintered at $1073 \mathrm{~K}, 1173 \mathrm{~K}$, and $1273 \mathrm{~K}\left(800{ }^{\circ} \mathrm{C}\right.$, $900{ }^{\circ} \mathrm{C}$, and $1000{ }^{\circ} \mathrm{C}$ ) show relatively similar variation trends, which can be roughly divided into two periods. In the first period, the currents increase from approximately 10 to $20 \mathrm{~mA}$ to around 30 to $40 \mathrm{~mA}$ with the increase of electroreduction time from 0 to 1 hours. Then, the currents converge to about $30 \mathrm{~mA}$ with further increasing electroreduction time to 2.5 hours (second period). The increase of current in the first period (from 0 to $\sim 1$ hours) may be mainly attributed to the three-phase interlines (3PIs) ${ }^{[44,45]}$ expand along the surface of the $\mathrm{Fe}_{2} \mathrm{O}_{3}$ pellet. The decrease of current in the second period (from $\sim 1$ to 2.5 hours) may be caused by the relatively low electronic conductivity of the reduction-generated iron layer and the relatively slow mass transfer from the interior of pellet precursor to the bulk aqueous $\mathrm{NaOH}$ solution. ${ }^{[44,45]}$ The second current increase during the intermediate stage $(\sim 1.5$ to 2.5 hours $)$ for $1273 \mathrm{~K}\left(1000{ }^{\circ} \mathrm{C}\right)$ case in Figure 5 may be caused by various factors, such as the catalytic effects of the reaction intermediates. Moreover, the reductiongenerated iron particles can grow and interconnect together gradually to increase the electronic conductivity of the iron layer, which may also contribute to create the second current increase during the intermediate process. The current-time curves recorded from the electroreduction of the $\mathrm{Fe}_{2} \mathrm{O}_{3}$ pellets sintered at $1373 \mathrm{~K}, 1473 \mathrm{~K}$, and $1573 \mathrm{~K}\left(1100{ }^{\circ} \mathrm{C}, 1200{ }^{\circ} \mathrm{C}\right.$, and $1300{ }^{\circ} \mathrm{C}$ ) show another distinct variation feature. In the initial period (from 0 to $\sim 1$ hours), the currents also increase with increasing electroreduction time. However, the currents almost maintain at a relatively stable value (30 to $40 \mathrm{~mA}$ ) in the second period (from $\sim 1$ 


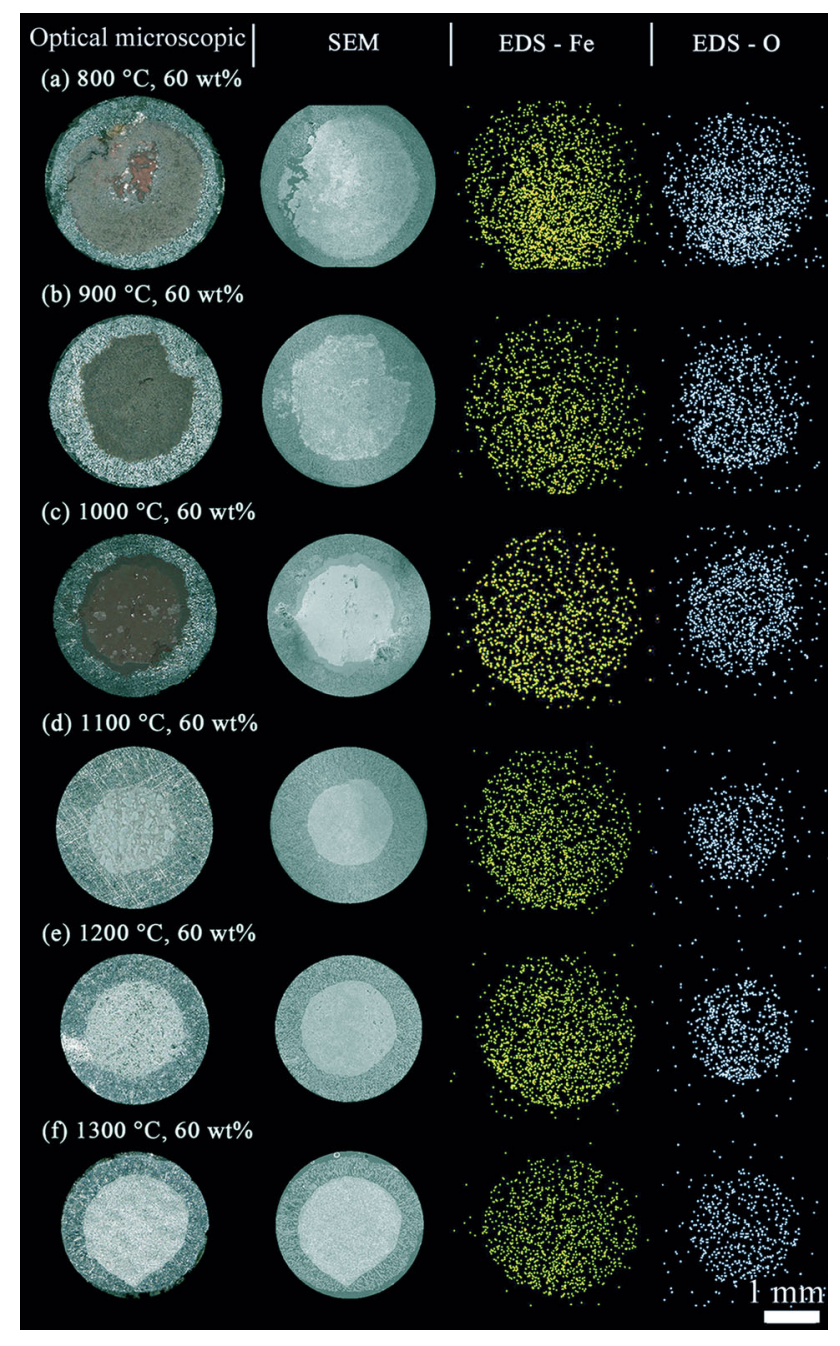

Fig. 4 - (a) through $(f)$ Optical microscopic images, SEM images and the corresponding elemental $(\mathrm{Fe}$ and $\mathrm{O})$ maps of the cross sections of the partially electroreduced $\mathrm{Fe}_{2} \mathrm{O}_{3}$ pellets, their corresponding precursors $\left(\mathrm{Fe}_{2} \mathrm{O}_{3}\right.$ pellets) were sintered in air for $2 \mathrm{~h}$ at $1073 \mathrm{~K}$ $\left(800{ }^{\circ} \mathrm{C}\right)(a), 1173 \mathrm{~K}\left(900^{\circ} \mathrm{C}\right)(b), 1273 \mathrm{~K}\left(1000{ }^{\circ} \mathrm{C}\right)(c), 1373 \mathrm{~K}$ $\left(1100{ }^{\circ} \mathrm{C}\right)(d), 1473 \mathrm{~K}\left(1200{ }^{\circ} \mathrm{C}\right)(e), 1573 \mathrm{~K}\left(1300{ }^{\circ} \mathrm{C}\right)(f)$, respectively, and the electroreduction processes were carried out in $60 \mathrm{wt}$ pct aqueous $\mathrm{NaOH}$ solution at $383 \mathrm{~K}\left(110^{\circ} \mathrm{C}\right)$ and $1.7 \mathrm{~V}$ for $2.5 \mathrm{~h}$.

to 2.5 hours). Especially, the current-time curve obtained from the electroreduction of the $\mathrm{Fe}_{2} \mathrm{O}_{3}$ pellet sintered $1373 \mathrm{~K}\left(1100{ }^{\circ} \mathrm{C}\right)$ exhibits large and stable value (around $40 \mathrm{~mA}$ ) during the period of 0.5 to 2.5 hours. Higher current value means higher reaction rate during the electroreduction process, it can thus be concluded that the $\mathrm{Fe}_{2} \mathrm{O}_{3}$ pellet sintered at $1373 \mathrm{~K}$ $\left(1100{ }^{\circ} \mathrm{C}\right)$ can contribute to obtain a stable and fast electroreduction process based on the current observation (Figure 5), which is consistent with the results presented in Figure 4. The porosity of the $\mathrm{Fe}_{2} \mathrm{O}_{3}$ pellet precursor sintered at $1373 \mathrm{~K}\left(1100{ }^{\circ} \mathrm{C}\right)$ in this work is measured to be approximately 15 pct (Figure 2(b)), which has been experimentally proven to be the optimum porosity for the electroreduction process, and it may also be partially responsible for the large current observation presented in Figure 5. However, the final porosity of the precursor depends on various

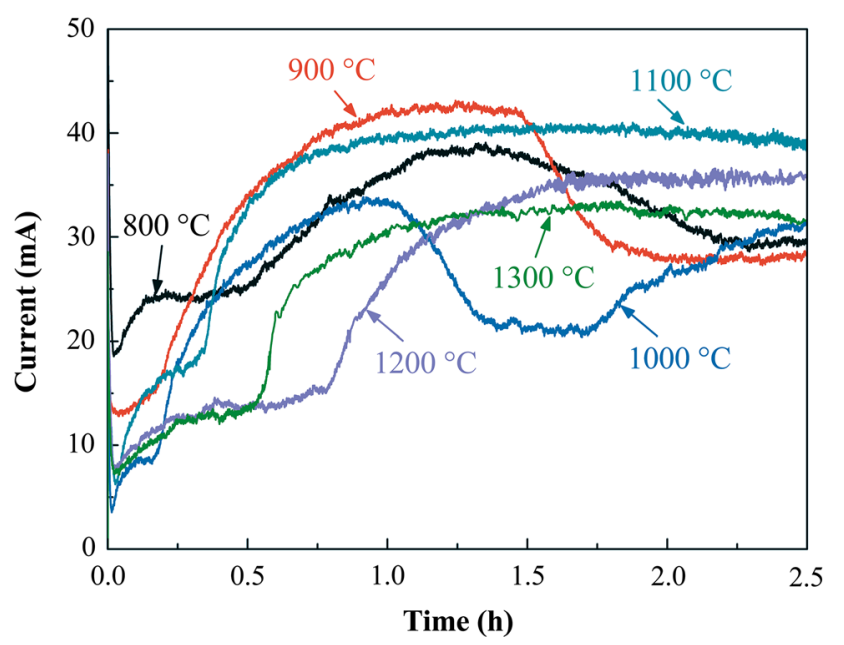

Fig. 5-Current-time curves of the electroreduction of $\mathrm{Fe}_{2} \mathrm{O}_{3}$ pellets (sintered at the indicated temperatures in air for $2 \mathrm{~h}$ ) in $60 \mathrm{wt}$ pct aqueous $\mathrm{NaOH}$ solution at $383 \mathrm{~K}\left(110^{\circ} \mathrm{C}\right)$ and $1.7 \mathrm{~V}$ for $2.5 \mathrm{~h}$.

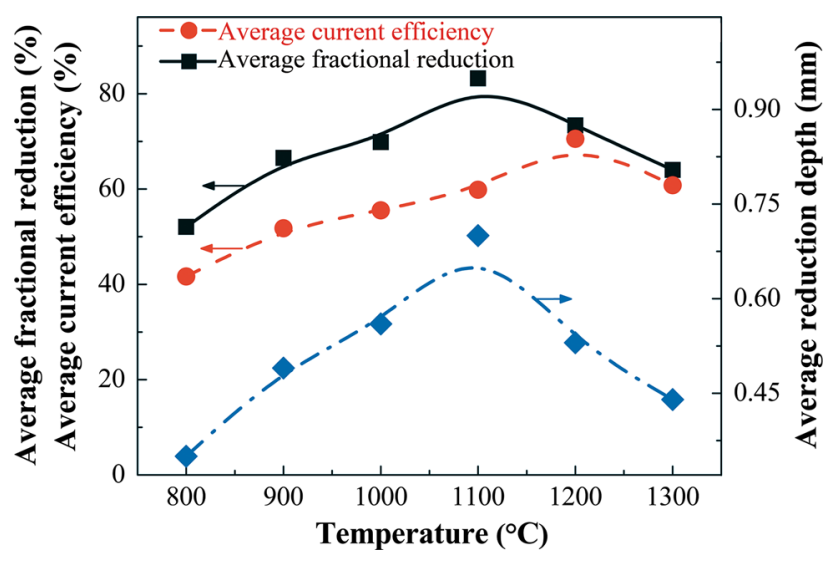

Fig. 6-Average fractional reduction, average current efficiency and average reduction depth of the electroreduction of $\mathrm{Fe}_{2} \mathrm{O}_{3}$ pellets [sintered at $1073 \mathrm{~K}$ to $1573 \mathrm{~K}\left(800{ }^{\circ} \mathrm{C}\right.$ to $\left.1300{ }^{\circ} \mathrm{C}\right)$ in air for $2 \mathrm{~h}$ ] in 60 wt pet aqueous $\mathrm{NaOH}$ solution at $383 \mathrm{~K}\left(110^{\circ} \mathrm{C}\right)$ and $1.7 \mathrm{~V}$ for $2.5 \mathrm{~h}$.

parameters, such as the type/structure of the oxide precursor and the sintering condition. In addition, the connectivity of the pores can influence the accessibility of the electrolyte and the migration of the ionic species. The fluid flow motion in the bulk electrolyte created by the gas evolution at the anode may also at least partially influence the mobility of the ionic species during electroreduction process.

The average fractional reduction, average current efficiency, and average reduction depth during electroreduction process are roughly evaluated/calculated and shown in Figure 6. The unreacted core is assumed to be a spherical core and thus the average reduction depth can be measured from Figure 4 based on the unreactedcore-shrinking approximation. ${ }^{[46,47]}$ The average fractional reduction $\left(y_{\mathrm{afr}}\right)$ is roughly calculated based on the unreacted $\mathrm{Fe}_{2} \mathrm{O}_{3}$ core volume ( $V_{\text {core }}$ ) and the reacted $\mathrm{Fe}_{2} \mathrm{O}_{3}$ volume $\left(V_{\text {initial }}-V_{\text {core }}\right)$ through the equation, i.e., $y_{\mathrm{afr}}=\left[\left(V_{\text {initial }}-V_{\text {core }}\right) / V_{\text {initial }}\right]$. The average 
current efficiency is also roughly evaluated from Figure 5 based on Faraday's law and the calculated average fractional reduction. The electroreduction process generally shows good reproducibility. However, the average fractional reduction and average current efficiency can be influenced by various factors, such as the porosity of the sintered $\mathrm{Fe}_{2} \mathrm{O}_{3}$ pellet and the concentration of $\mathrm{NaOH}$ aqueous electrolyte. Therefore, slight deviations of the calculated average fractional reduction/average current efficiency may be inevitably generated. These evaluations/calculations can only be used as preliminary estimates for the electroreduction process. It can be seen that the average fractional reduction, average current efficiency and average reduction depth are interrelated, which increase with the increase of the precursor's sintering temperature $\left[<1373 \mathrm{~K}\left(1100^{\circ} \mathrm{C}\right)\right]$. Maximum values of the average fractional reduction and average reduction depth appear when the precursor's sintering temperature is $1373 \mathrm{~K}\left(1100{ }^{\circ} \mathrm{C}\right)$, and the average current efficiency reaches its maximum when the precursor's sintering temperature is $1473 \mathrm{~K}\left(1200{ }^{\circ} \mathrm{C}\right)$. These results further demonstrate that the optimum sintering temperature for $\mathrm{Fe}_{2} \mathrm{O}_{3}$ precursor is around $1373 \mathrm{~K}\left(1100^{\circ} \mathrm{C}\right)$. The average fractional reduction, average current efficiency and average reduction depth decrease with the precursor's sintering temperature further increases to $1473 \mathrm{~K}$ and $1573 \mathrm{~K}\left(1200{ }^{\circ} \mathrm{C}\right.$ and $1300{ }^{\circ} \mathrm{C}$ ). These interesting variations may be attributed to the different porosities and phase compositions (Figures 2 and 3) of the pellets precursors sintered at different temperatures.

\section{B. Influence of the Concentration of $\mathrm{NaOH}$ Aqueous Electrolyte on the Electroreduction Process}

The concentration of $\mathrm{NaOH}$ aqueous electrolyte also has important effect on the electroreduction process. In order to investigate the electroreduction processes in different concentrations of aqueous $\mathrm{NaOH}$ solution, experiments were also carried out in 50 to $70 \mathrm{wt}$ pct aqueous $\mathrm{NaOH}$ solution. The optical microscopic images, SEM images, and the corresponding elemental $(\mathrm{Fe}$ and $\mathrm{O}$ ) maps of the cross sections of the $\mathrm{Fe}_{2} \mathrm{O}_{3}$ pellets partially electroreduced in 50 to $70 \mathrm{wt}$ pct aqueous $\mathrm{NaOH}$ solution are shown in Figure 7. The $\mathrm{Fe}_{2} \mathrm{O}_{3}$ pellets sintered at $1373 \mathrm{~K}\left(1100{ }^{\circ} \mathrm{C}\right)$ in air for 2 hours were used as the precursors for the electroreduction experiments in different concentrations of $\mathrm{NaOH}$ aqueous electrolyte. As evidenced from the figure, it is obvious that the concentration of $\mathrm{NaOH}$ aqueous electrolyte has a significant influence on the electroreduction process. The reaction degrees (average reduction depths) observed in Figure 7 clearly show that 60 wt pet aqueous $\mathrm{NaOH}$ solution is more suitable for the electroreduction process than the other concentrations of aqueous $\mathrm{NaOH}$ solution. In addition, there seems to be three different phases in Figure 7(a). The reduction-generated Fe phase and the unreacted $\mathrm{Fe}_{2} \mathrm{O}_{3}$ phase can be clearly identified, therefore, the third phase may be attributed to the intermediate products, such as $\mathrm{Fe}_{3} \mathrm{O}_{4} \cdot{ }^{[16]}$ These observations further confirm that the concentration of $\mathrm{NaOH}$ aqueous electrolyte can influence the reaction process.
The current-time curves recorded during the electroreduction processes carried out in different concentrations of aqueous $\mathrm{NaOH}$ solution are shown in Figure 8(a). The current-time curves show homologous variation trends, which are different from the currenttime curves shown in Figure 5. This observation further demonstrates that the precursor's sintering temperature and the concentration of $\mathrm{NaOH}$ aqueous electrolyte have critical influences on the electroreduction process. However, it seems that the electroreduction process (corresponding to the variation feature of current, Figure 5) is generally affected by the presintering process of precursor, and the reaction rate [corresponding to the current value, Figure 8(a)] is mainly influenced by the concentration of aqueous $\mathrm{NaOH}$ solution. The current generated during the electroreduction process increases with increasing the concentration of aqueous $\mathrm{NaOH}$ solution from 50 to $60 \mathrm{wt}$ pct, as shown in Figures 8(a) and (b). A maximum value of current appears when the concentration of aqueous $\mathrm{NaOH}$ solution is $60 \mathrm{wt}$ pct (Figure 8(b)). Then, the current decreases with further increasing the concentration of aqueous $\mathrm{NaOH}$ solution to $70 \mathrm{wt}$ pct. It should be noted that the electrochemical windows of aqueous $\mathrm{NaOH}$ solution with different concentrations are almost the same (approximately $1.75 \mathrm{~V}$ in this experiment). The viscosity of aqueous $\mathrm{NaOH}$ solution generally increases with increasing the $\mathrm{OH}^{-}$concentration. Therefore, the different current values (Figure 8) may be partially attributed to the different viscosities of $\mathrm{NaOH}$ aqueous electrolyte. Higher $\mathrm{OH}^{-}$concentration may contribute to form a surface barrier layer around the $\mathrm{Fe}_{2} \mathrm{O}_{3}$ pellet/particle and thus influences the mobility of the ionic species. In addition, the different solubilities of iron oxides (including sub-oxides) in different concentrations of aqueous $\mathrm{NaOH}$ solution may also be partially responsible for the different current values. ${ }^{[1,15]}$ The current-time curves also show that $60 \mathrm{wt}$ pct aqueous $\mathrm{NaOH}$ solution is the optimum electrolyte for the electroreduction process in this work. It is worth noting that almost all of the current-time curves (Figures 5 and 8(a)) increase sharply at approximately 0.5 hours. Actually, this observation can be generally explained by the 3PIs reaction mechanism. ${ }^{[9,44,45]}$ However, the catalytic effects of the reaction intermediates and the improvement in the accessibility of $\mathrm{NaOH}$ aqueous electrolyte to the reaction area may also be partially responsible for the sudden increase of current. Moreover, the current-time curves (Figures 5 and 8(a)) show different initial current values, which are mainly attributed to the different volumes (surface areas/ reaction areas) of the $\mathrm{Fe}_{2} \mathrm{O}_{3}$ pellets sintered at different temperatures (as shown in Figure 2) and the different concentrations/viscosities of aqueous $\mathrm{NaOH}$ solution. Especially, the current-time curve for $70 \mathrm{wt}$ pct aqueous $\mathrm{NaOH}$ solution (Figure 8(a)) shows the initial current value is approximately $0 \mathrm{~mA}$, which is different from the others. This observation may indicate that the electroreduction reactions are relatively difficult and the side reactions in the system are suppressed at this concentration. 


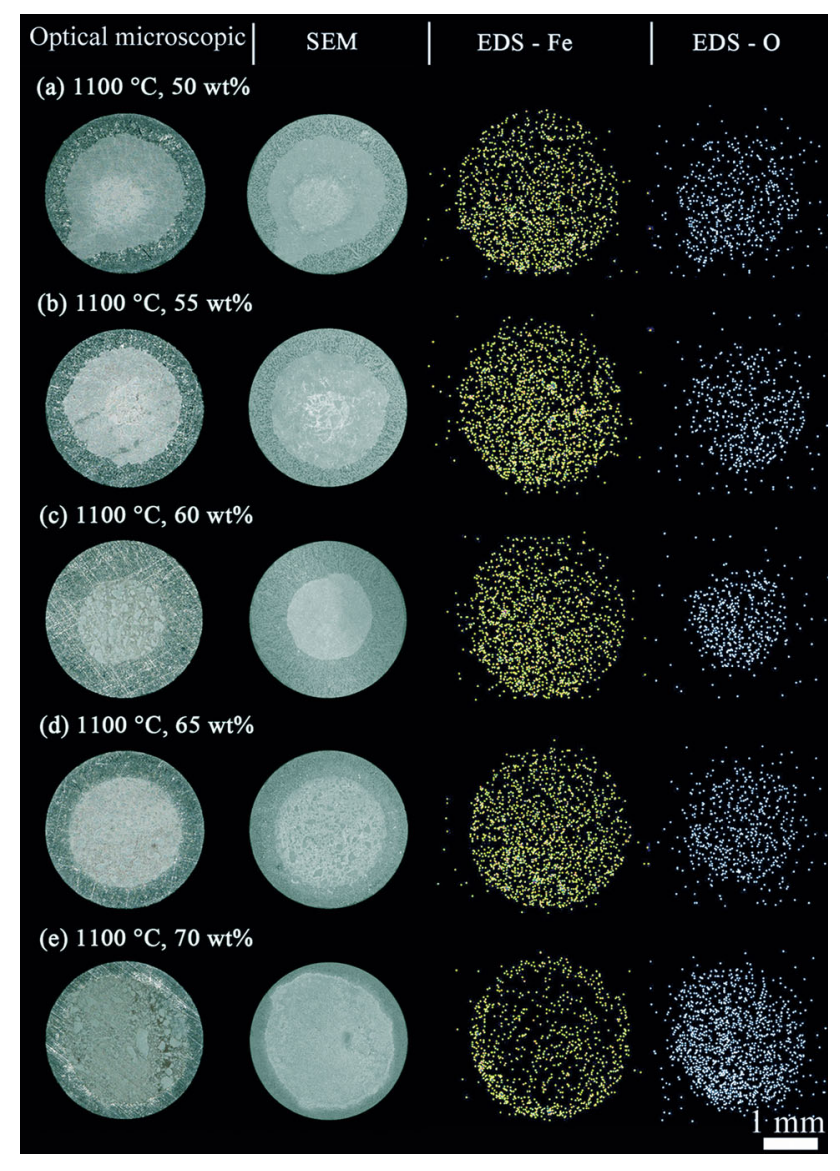

Fig. 7-(a) through (e) Optical microscopic images, SEM images and the corresponding elemental $(\mathrm{Fe}$ and $\mathrm{O})$ maps of the cross sections of the partially electroreduced $\mathrm{Fe}_{2} \mathrm{O}_{3}$ pellets, their corresponding precursors $\left(\mathrm{Fe}_{2} \mathrm{O}_{3}\right.$ pellets) were sintered at $1373 \mathrm{~K}\left(1100{ }^{\circ} \mathrm{C}\right)$ in air for $2 \mathrm{~h}$ and the electroreduction processes were carried out in $50 \mathrm{wt}$ pct $(a), 55$ wt pct $(b), 60 \mathrm{wt}$ pct $(c), 65 \mathrm{wt}$ pct $(d), 70 \mathrm{wt}$ pct $(e)$ aqueous $\mathrm{NaOH}$ solutions at $383 \mathrm{~K}\left(110^{\circ} \mathrm{C}\right)$ and $1.7 \mathrm{~V}$ for $2.5 \mathrm{~h}$.

The average fractional reduction, average current efficiency and average reduction depth of the electroreduction process in different concentrations of aqueous $\mathrm{NaOH}$ solution are also roughly evaluated/calculated based on Figures 7 and 8(a), as illustrated in Figure 9. The average fractional reduction and average reduction depth also show coincident variation trends, which increase with increasing the concentration of aqueous $\mathrm{NaOH}$ solution from 50 to 60 wt pct, and then decrease with the further increase of the concentration of aqueous $\mathrm{NaOH}$ solution to 70 wt pct. In contrast, the average current efficiency keeps at a relatively stable level of approximately 60 pct in 50 to $65 \mathrm{wt}$ pct aqueous $\mathrm{NaOH}$ solution. The average current efficiency increases to about 80 pct when the concentration of aqueous $\mathrm{NaOH}$ solution is $70 \mathrm{wt}$ pct. The loss of current efficiency for the electroreduction process may be attributed, at least partially, to the side reaction (such as the hydrogen evolution reaction, i.e., $2 \mathrm{H}_{2} \mathrm{O}+2$ $\left.\mathrm{e}^{-} \rightarrow \mathrm{H}_{2}+2 \mathrm{OH}^{-}\right)^{[14]}$ and the inhibition of the dissolved iron species. ${ }^{[14,15]}$

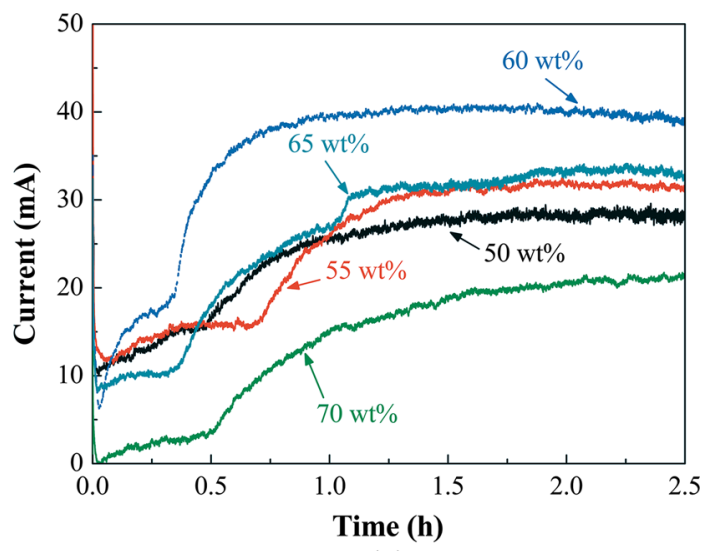

(a)

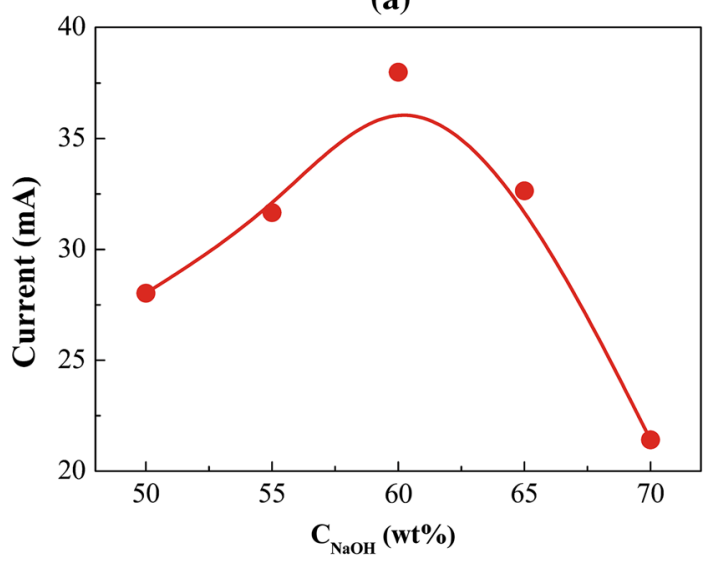

(b)

Fig. 8- (a) Current-time curves of the electroreduction of $\mathrm{Fe}_{2} \mathrm{O}_{3}$ pellets [sintered at $1373 \mathrm{~K}\left(1100{ }^{\circ} \mathrm{C}\right)$ in air for $2 \mathrm{~h}$ ] in different concentrations of aqueous $\mathrm{NaOH}$ solution at $383 \mathrm{~K}\left(110^{\circ} \mathrm{C}\right)$ and $1.7 \mathrm{~V}$ for $2.5 \mathrm{~h},(b)$ typical current values recorded at $2.5 \mathrm{~h}$ after the application of $1.7 \mathrm{~V}$ potential in different concentrations of aqueous $\mathrm{NaOH}$ $\left(\mathrm{C}_{\mathrm{NaOH}}\right)$ solution at $383 \mathrm{~K}\left(110^{\circ} \mathrm{C}\right)$.

\section{Influence of the Electroreduction Time on the Electroreduction Process}

Figures 4 and 7 exhibit that the electroreduction of $\mathrm{Fe}_{2} \mathrm{O}_{3}$ pellet generally proceeds from the surface of the pellet to the pellet's interior. In order to investigate the reaction progress in detail, systematically experiments were performed by using the $\mathrm{Fe}_{2} \mathrm{O}_{3}$ pellets sintered at $1373 \mathrm{~K}\left(1100^{\circ} \mathrm{C}\right)$ in air for 2 hours as precursors in 60 wt pct aqueous $\mathrm{NaOH}$ solution at $383 \mathrm{~K}\left(110^{\circ} \mathrm{C}\right)$ and $1.7 \mathrm{~V}$ for different durations. The partially electroreduced pellets were taken periodically during the electroreduction process and characterized, as shown in Figure 10. The typical shrinking-core reaction process is clearly observed through Figures 10(a) through (i). The unreacted $\mathrm{Fe}_{2} \mathrm{O}_{3}$ core is surrounded by a spherical shell of porous metallized iron crystals. A spherical $\mathrm{Fe}_{2} \mathrm{O}_{3}$ pellet with diameter of approximately $3.2 \mathrm{~mm}$ and weight around $60 \mathrm{mg}$ can be directly electroreduced to iron in 60 wt pct aqueous $\mathrm{NaOH}$ electrolyte at $383 \mathrm{~K}$ $\left(110^{\circ} \mathrm{C}\right)$ and $1.7 \mathrm{~V}$ within 4 hours. 


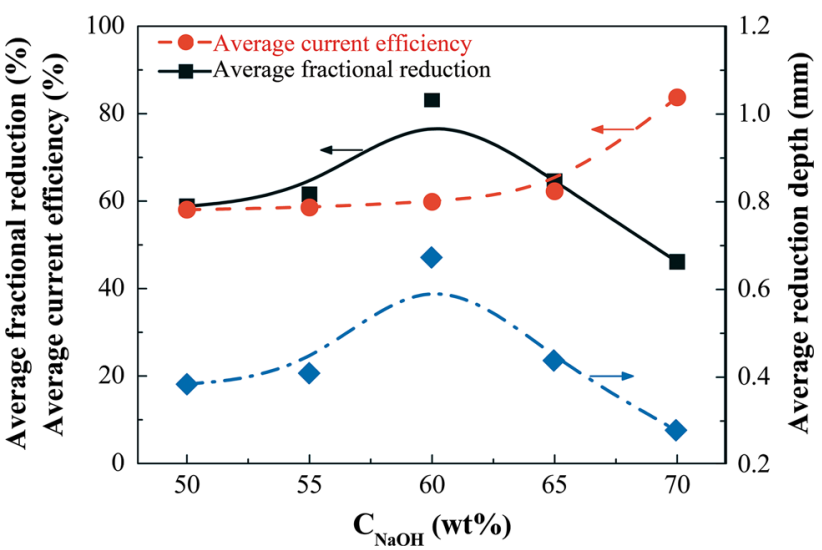

Fig. 9-Average fractional reduction, average current efficiency and average reduction depth of the electroreduction of $\mathrm{Fe}_{2} \mathrm{O}_{3}$ pellets [sintered at $1373 \mathrm{~K}\left(1100{ }^{\circ} \mathrm{C}\right)$ in air for $2 \mathrm{~h}$ ] in different concentrations of aqueous $\mathrm{NaOH}\left(\mathrm{C}_{\mathrm{NaOH}}\right)$ solution at $383 \mathrm{~K}\left(110^{\circ} \mathrm{C}\right)$ and $1.7 \mathrm{~V}$ for $2.5 \mathrm{~h}$.

The typical current-time curve of the electroreduction of $\mathrm{Fe}_{2} \mathrm{O}_{3}$ pellet in 60 wt pct aqueous $\mathrm{NaOH}$ solution at $383 \mathrm{~K}\left(110^{\circ} \mathrm{C}\right)$ and $1.7 \mathrm{~V}$ for 4.5 hours is shown in Figure 11. The current-time curve can be divided into three periods, as labeled in the figure. In the first period (from 0 to $\sim 1$ hours), the current increases gradually and then a sudden increase of current occurs at around 0.5 hours, the two current increase stages may mainly correspond to the external surface of $\mathrm{Fe}_{2} \mathrm{O}_{3}$ pellet precursor becomes accessible to $\mathrm{NaOH}$ aqueous electrolyte and the 3PIs reaction area expands rapidly along the surface of the pellet, respectively. Then, the reaction rate reaches its maximum when the whole surface of the pellet is metalized (second period). With the unreacted core $\left(\mathrm{Fe}_{2} \mathrm{O}_{3}\right)$ shrinking gradually, the reaction area decreases, therefore, the current decreases gradually until the whole pellet is completely electroreduced (third period). The current-time curve clearly shows that the electroreduction process can be finished within approximately 4 hours when the current drops to a stable level, then the current keeps at the stable level during $\sim 4$ to 4.5 hours, which is mainly attributed to the residual current.

Based on Figure 10, the unreacted $\mathrm{Fe}_{2} \mathrm{O}_{3}$ (core) volume and the average reduction depth (electroreduction-generated metallic layer) are still roughly evaluated/calculated and plotted in Figure 12. The unreacted $\mathrm{Fe}_{2} \mathrm{O}_{3}$ core shrinks gradually with electroreduction time, the variation of the volume of $\mathrm{Fe}_{2} \mathrm{O}_{3}$ core $(y)$ with electroreduction time $(x)$ can be expressed as the equation, $y=0.6655 x^{2}-6.1894 x+14.2385$, by data fitting. In addition, the average reduction depth measured from Figure 10 can be classified to three parts, as labeled in Figure 12. During the surface electroreduction process, the average reduction depth increases slowly. In contrast, the average reduction depth increases relatively quickly during the body (core) electroreduction process. When $\mathrm{Fe}_{2} \mathrm{O}_{3}$ pellet is completely electroreduced, the pellet shrinks slightly from diameter of $3.0 \mathrm{~mm}$ (Figure 2(a)) to approximately $2.9 \mathrm{~mm}$ (Figure 12).

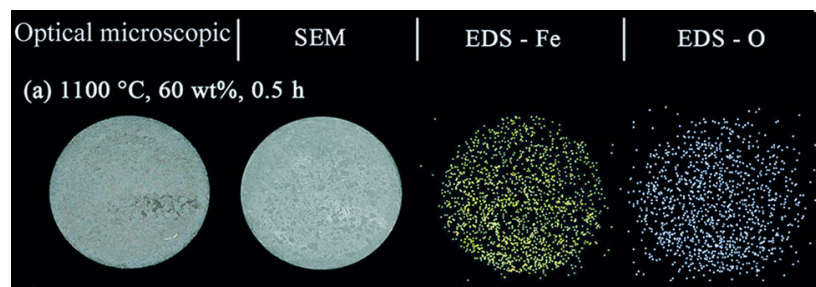

(b) $1100^{\circ} \mathrm{C}, 60 \mathrm{wt} \%, 1 \mathrm{~h}$
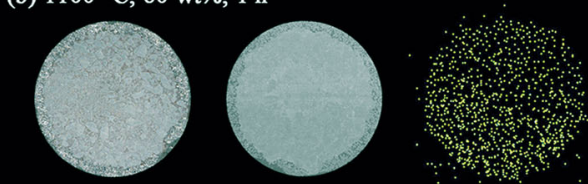

(c) $1100{ }^{\circ} \mathrm{C}, 60 \mathrm{wt} \%, 1.5 \mathrm{~h}$
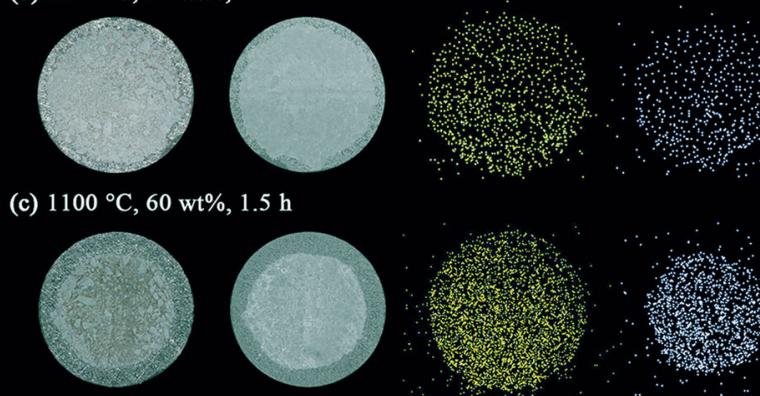

(d) $1100{ }^{\circ} \mathrm{C}, 60 \mathrm{wt} \%, 2 \mathrm{~h}$

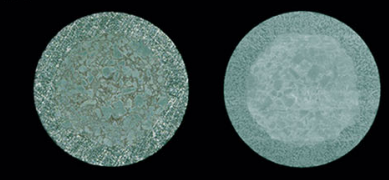

(e) $1100{ }^{\circ} \mathrm{C}, 60 \mathrm{wt} \%, 2.5 \mathrm{~h}$
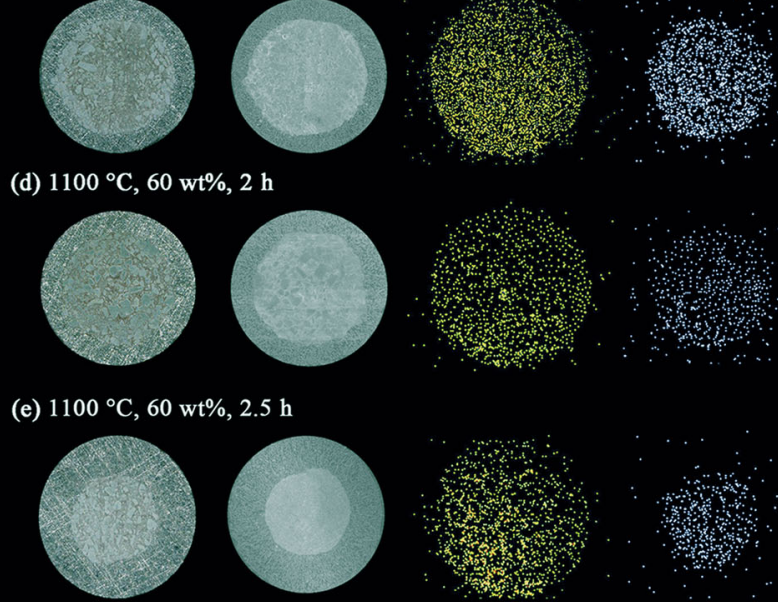

(f) $1100{ }^{\circ} \mathrm{C}, 60 \mathrm{wt} \%, 3 \mathrm{~h}$

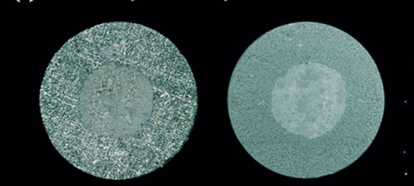

(g) $1100{ }^{\circ} \mathrm{C}, 60 \mathrm{wt} \%, 3.5 \mathrm{~h}$
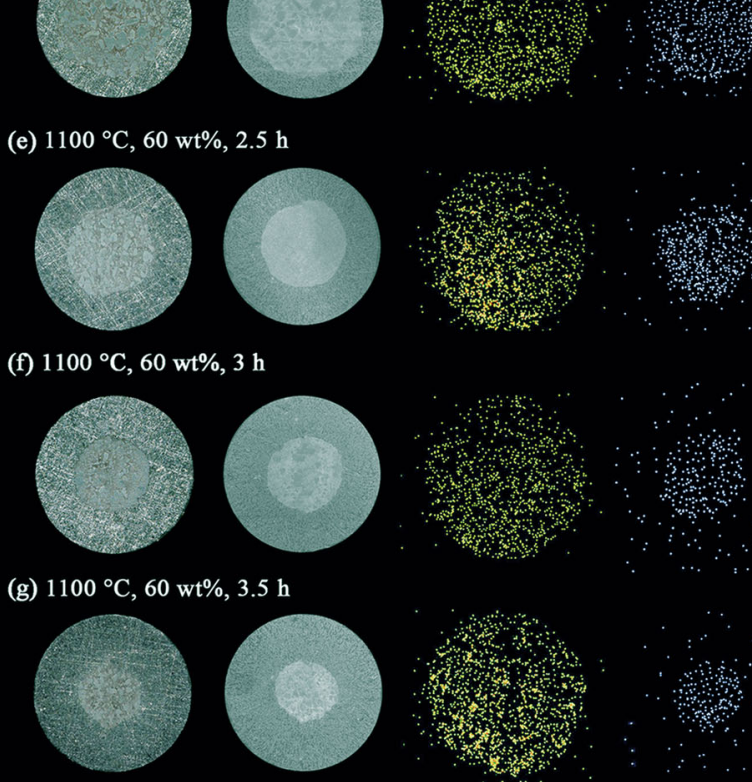

(h) $1100{ }^{\circ} \mathrm{C}, 60 \mathrm{wt} \%, 4 \mathrm{~h}$

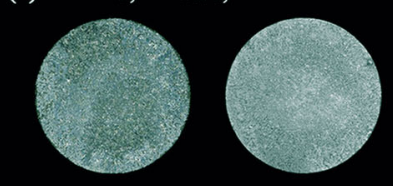

(i) $1100^{\circ} \mathrm{C}, 60 \mathrm{wt} \%, 4.5 \mathrm{~h}$

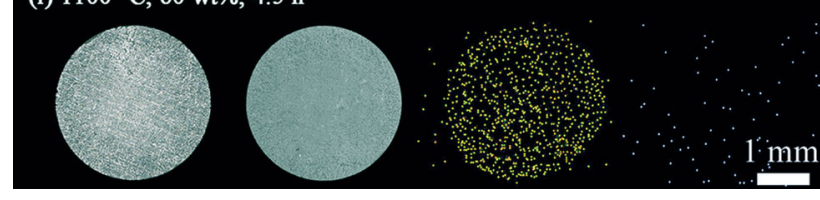

Fig. 10 - (a) through (i) Optical microscopic images, SEM images and the corresponding elemental ( $\mathrm{Fe}$ and $\mathrm{O}$ ) maps of the cross sections of the partially/completely electroreduced $\mathrm{Fe}_{2} \mathrm{O}_{3}$ pellets, their corresponding precursors $\left(\mathrm{Fe}_{2} \mathrm{O}_{3}\right.$ pellets $)$ were sintered at $1373 \mathrm{~K}$ $\left(1100{ }^{\circ} \mathrm{C}\right)$ in air for $2 \mathrm{~h}$ and the electroreduction processes were carried out in $60 \mathrm{wt}$ pet aqueous $\mathrm{NaOH}$ solution at $383 \mathrm{~K}\left(110{ }^{\circ} \mathrm{C}\right)$ and $1.7 \mathrm{~V}$ for $0.5 \mathrm{~h}(a), 1 \mathrm{~h}(b), 1.5 \mathrm{~h}(c), 2 \mathrm{~h}(d), 2.5 \mathrm{~h}(e), 3 \mathrm{~h}(f), 3.5 \mathrm{~h}$ $(g), 4 \mathrm{~h}(h)$ and $4.5 \mathrm{~h}(i)$. 


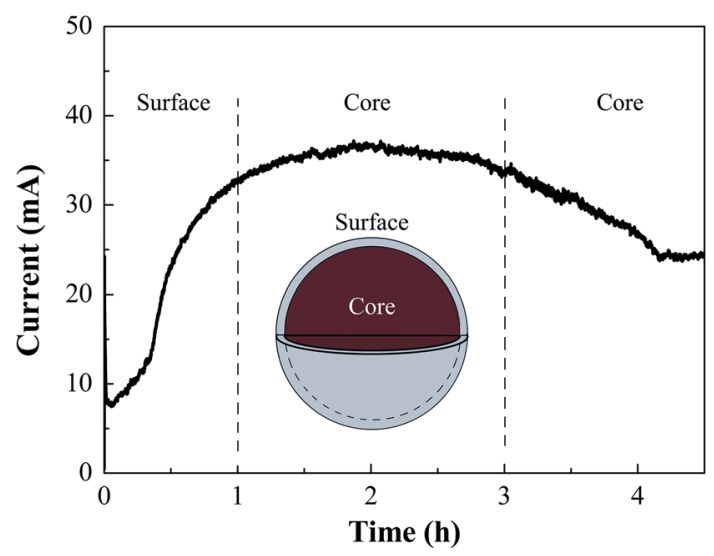

Fig. 11-Typical current-time curve of the electroreduction of $\mathrm{Fe}_{2} \mathrm{O}_{3}$ pellet [sintered at $1373 \mathrm{~K}\left(1100{ }^{\circ} \mathrm{C}\right)$ in air for $2 \mathrm{~h}$ ] in 60 wt pet aqueous $\mathrm{NaOH}$ solution at $383 \mathrm{~K}\left(110^{\circ} \mathrm{C}\right)$ and $1.7 \mathrm{~V}$ for $4.5 \mathrm{~h}$. The inset is the schematic illustration of the variation of $\mathrm{Fe}_{2} \mathrm{O}_{3}$ pellet during the electroreduction process

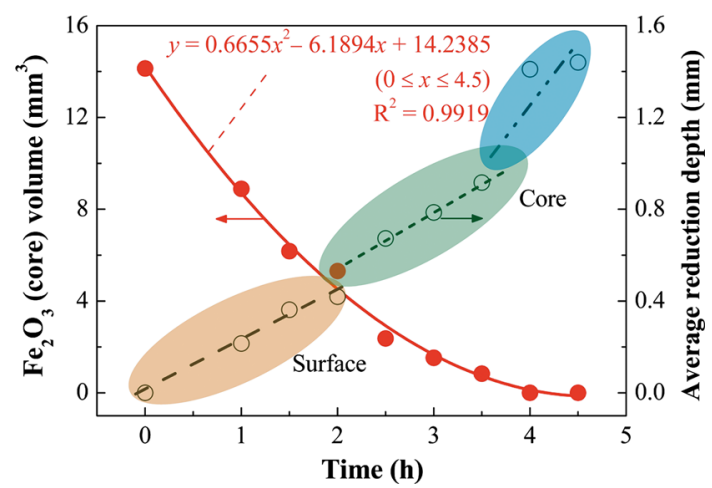

Fig. 12-Variations of the $\mathrm{Fe}_{2} \mathrm{O}_{3}$ (unreacted core) volume and average reduction depth with electroreduction time during the electroreduction of $\mathrm{Fe}_{2} \mathrm{O}_{3}$ pellet in 60 wt pet aqueous $\mathrm{NaOH}$ solution at $383 \mathrm{~K}\left(110^{\circ} \mathrm{C}\right)$ and $1.7 \mathrm{~V}$ for $4.5 \mathrm{~h}$, the solid line is obtained by data fitting.

\section{Typical Shrinking-core Reaction Process and Reaction Mechanisms}

1. Typical shrinking-core reaction process

Figure 13 detailedly displays the SEM images of the cross sections of the partially electroreduced pellets taken periodically from the electroreduction process. It can be seen from Figure 13(a) that the initial reaction firstly occurs at the contact point of $\mathrm{Fe}_{2} \mathrm{O}_{3}$ pellet/porous nickel electronic conductor. Then, the electroreductiongenerated metallic iron further acts as new extended electronic conductor and thus the subsequent electroreduction process can proceed continuously. Metallic iron layer comprising dendritic iron crystals is first formed on the surface of $\mathrm{Fe}_{2} \mathrm{O}_{3}$ pellet precursor and then extends gradually into the pellet's interior along the radial direction (Figures 13(b) through (e)). The XRD pattern inserted in Figure 13(e) reveals that $\mathrm{Fe}_{2} \mathrm{O}_{3}$ pellet precursor has been completely electroreduced to iron. Figure 13(f) is the schematic illustration of the variation of $\mathrm{Fe}_{2} \mathrm{O}_{3}$ pellet during the electroreduction process, which illustrates the initial reaction point and the typical shrinking-core process.

\section{Solid state electroreduction mechanism}

Figure 14 further shows a typical back scattered electron (BSE) image of the reaction interface and its corresponding schematic illustration, the reaction area is determined to be composed of three parts/phases, i.e., $\mathrm{Fe}_{2} \mathrm{O}_{3}, \mathrm{Fe}_{3} \mathrm{O}_{4}$ and $\mathrm{Fe}$. This observation is consistent with the previous work. ${ }^{[16]} \mathrm{Fe}_{3} \mathrm{O}_{4}$ is usually generated as the intermediate product during the electroreduction of $\mathrm{Fe}_{2} \mathrm{O}_{3}$, e.g., $\mathrm{Fe}_{2} \mathrm{O}_{3}+\mathrm{Fe}(\mathrm{OH})_{3}^{-} \rightarrow \mathrm{Fe}_{3} \mathrm{O}_{4}+\mathrm{H}_{2} \mathrm{O}+$ $\mathrm{OH}^{-},{ }^{116]}{ }^{3}\left(\Delta G^{\circ} 383 \mathrm{~K}\left[110^{\circ} \mathrm{Cl}<-36.49 \mathrm{~kJ} / \mathrm{mol}\right) .^{[48-52]} \mathrm{In}\right.$ addition, a few small powdery electroreduction-generated iron grains are found in the reaction interface (the inset in Figure 14(a)), which suggests that the solid state electroreduction mechanism (Reactions [1] and [2]), i.e., $\mathrm{Fe}_{2} \mathrm{O}_{3} \rightarrow \mathrm{Fe}_{3} \mathrm{O}_{4} \rightarrow \mathrm{Fe}$, is likely to present in the electroreduction process. The electroreduction-generated
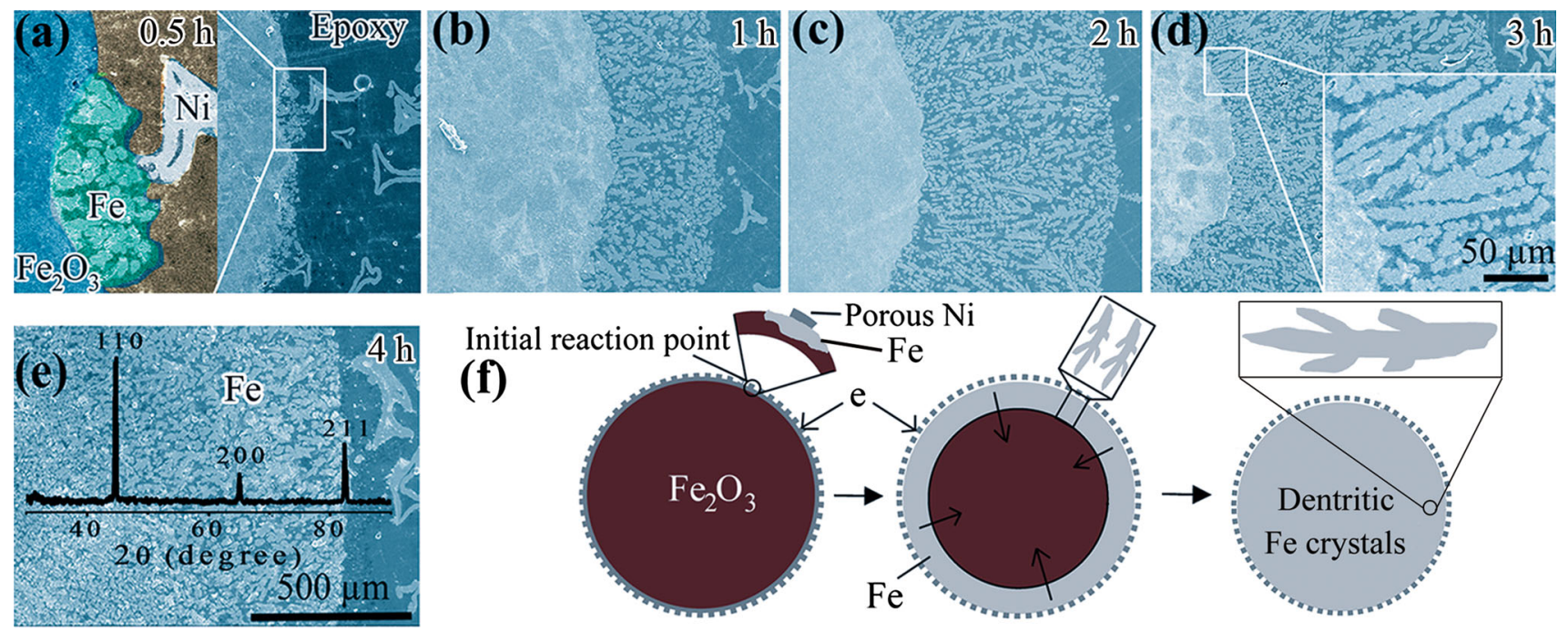

Fig. 13- (a) through (e) SEM images of the cross sections of the partially electroreduced $\mathrm{Fe}_{2} \mathrm{O}_{3}$ pellets [sintered at $1373 \mathrm{~K}\left(1100{ }^{\circ} \mathrm{C}\right)$ in air for $2 \mathrm{~h}$ ] taken periodically during the electroreduction process carried out in $60 \mathrm{wt}$ pet aqueous $\mathrm{NaOH}$ solution at $383 \mathrm{~K}\left(110^{\circ} \mathrm{C}\right)$ and $1.7 \mathrm{~V}$, the inset in $(e)$ is the XRD pattern of the obtained iron, $(f)$ schematic illustration of the typical shrinking-core reaction process. 

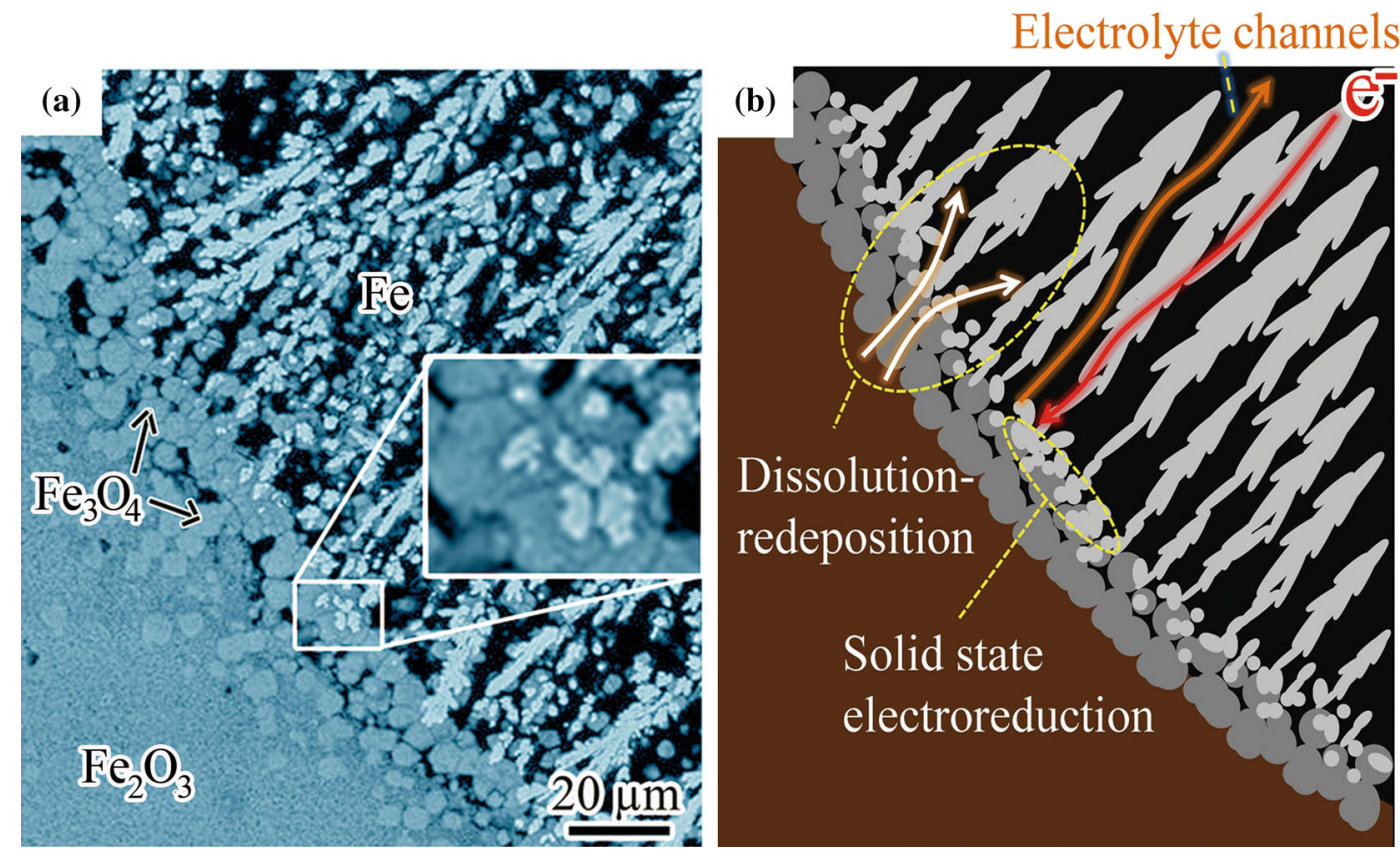

Fig. 14 - (a) Typical BSE image of the partially electroreduced $\mathrm{Fe}_{2} \mathrm{O}_{3}$ pellet showing the reaction interface, $(b)$ the corresponding schematic illustration of the reaction interface.

oxygen ion could then react with $\mathrm{H}_{2} \mathrm{O}$ to form $\mathrm{OH}^{-}$, i.e., $\mathrm{O}^{2-}+\mathrm{H}_{2} \mathrm{O} \rightarrow 2 \mathrm{OH}^{-}{ }^{[18]}$ Therefore, the overall reaction is expressed by Reaction [3]. ${ }^{[15]}$ The theoretical decomposition potentials $\left(E^{\circ}\right)$ for Reactions [1] through [3] have been calculated from the reported thermodynamic data. ${ }^{[48-52]}$

$$
3 \mathrm{Fe}_{2} \mathrm{O}_{3}+2 \mathrm{e}^{-} \rightarrow 2 \mathrm{Fe}_{3} \mathrm{O}_{4}+\mathrm{O}^{2-}\left(E^{\circ} 383 K\left[110^{\circ} \mathrm{C}\right]=0.96 \mathrm{~V}\right)
$$

$$
\mathrm{Fe}_{3} \mathrm{O}_{4}+8 \mathrm{e}^{-} \rightarrow 3 \mathrm{Fe}+4 \mathrm{O}^{2-}\left(E^{\circ}{ }_{383 \mathrm{~K}\left[110^{\circ} \mathrm{C}\right]}=1.28 \mathrm{~V}\right)
$$

$$
\begin{aligned}
& \mathrm{Fe}_{2} \mathrm{O}_{3}+3 \mathrm{H}_{2} \mathrm{O}+6 \mathrm{e}^{-} \rightarrow 2 \mathrm{Fe} \\
& \quad+6 \mathrm{OH}^{-}\left(E^{\circ}{ }_{383 \mathrm{~K}\left[110^{\circ} \mathrm{C}\right]}=\sim 0.78 \mathrm{~V}\right)
\end{aligned}
$$

\section{Dissolution-electrodeposition mechanism}

It is obvious that the electroreduction-generated metallic $\mathrm{Fe}$ shows a completely different morphology (dendritic crystals), as shown in Figures 13(d) and 14(a). Individual iron crystals are formed and grow dendritically toward the core of the pellet. The difference between the morphologies of the electroreduction-generated dendritic iron crystals and the initial $\mathrm{Fe}_{2} \mathrm{O}_{3}$ powder suggests that the dissolution of $\mathrm{Fe}_{2} \mathrm{O}_{3}$ may occur during the electroreduction process. ${ }^{[14]}$ Actually, comparing to the typical current-time curves of the electrodeoxidation of solid oxides in molten salts, ${ }^{[9,24,27,28,53]}$ the current-time curves shown in Figures 5, 8(a), and 11 display a small difference. The currents generated during the electrodeoxidation of solid oxides in molten salts generally increase to their maximum values and then decrease immediately. ${ }^{[53]}$ However, the currents generated during the electroreduction of iron(III) oxide in this experiment typically maintain at their maximum values for about 2 hours (Figure 11). This observation implies that the reaction routes of the electrodeoxidation of solid oxides in molten salts and the electroreduction of iron(III) oxide in alkaline solutions may be different (at least to some extent).

Actually, a trace amount of iron(III) oxide can dissolve in $\mathrm{NaOH}$ aqueous electrolyte in the form $\mathrm{Fe}(\mathrm{OH})_{4}^{-},{ }^{[14,15,54,55]}$ the corresponding dissolution reaction is $\mathrm{Fe}_{2} \mathrm{O}_{3}+3 \mathrm{H}_{2} \mathrm{O}+2 \mathrm{OH}^{-} \rightarrow 2 \mathrm{Fe}(\mathrm{OH})_{4}^{-} \cdot{ }^{-[15]}$ Simultaneously, the intermediate product $\mathrm{Fe}_{3} \mathrm{O}_{4}$ can also be dissolved in aqueous $\mathrm{NaOH}$ solution by the electroassisted dissolution Reaction [4]. ${ }^{[16,18]}$ Actually, Na$\mathrm{FeO}_{2}$ can be generated as the intermediate product during the electroreduction process by Reaction [5], and then part of $\mathrm{NaFeO}_{2}$ can convert into $\mathrm{Fe}(\mathrm{OH})_{4}^{-}$following the dissolution Reaction [6]. The concentrations of the dissolved iron species (which are mainly believed to be $\mathrm{Fe}(\mathrm{OH})_{4}^{-}$and/or $\left.\mathrm{Fe}(\mathrm{OH})_{3}^{-}\right)^{[14-16]}$ in the $\mathrm{Fe}_{2} \mathrm{O}_{3^{-}}$, $\mathrm{Fe}_{3} \mathrm{O}_{4^{-}}$and $\mathrm{NaFeO}_{2}$-saturated 50 wt pct aqueous $\mathrm{NaOH}$ solutions at $383 \mathrm{~K}\left(110{ }^{\circ} \mathrm{C}\right)$ were determined to be around 2 to $3 \times 10^{-3} \mathrm{M},{ }^{[14,15,55]} 3.14 \times 10^{-3} \mathrm{M}$ and $>1.28 \times 10^{-3} \mathrm{M}^{[56]}$, respectively. It was also suggested that the solubilities of iron species in aqueous $\mathrm{NaOH}$ solution generally increase with increasing temperature and $\mathrm{NaOH}$ concentration. ${ }^{[14,54]}$ Therefore, in order to evaluate the possible electrodeposition routes during the electroreduction process, experiments were conducted to quantify the electrodeposition routes from the aqueous $\mathrm{NaOH}$ solutions saturated with $\mathrm{Fe}_{2} \mathrm{O}_{3}$ and $\mathrm{NaFeO}_{2}$, respectively. The microstructures of the iron particles electrodeposited in $\mathrm{Fe}_{2} \mathrm{O}_{3^{-}}$and $\mathrm{NaFeO}_{2}$-saturated 

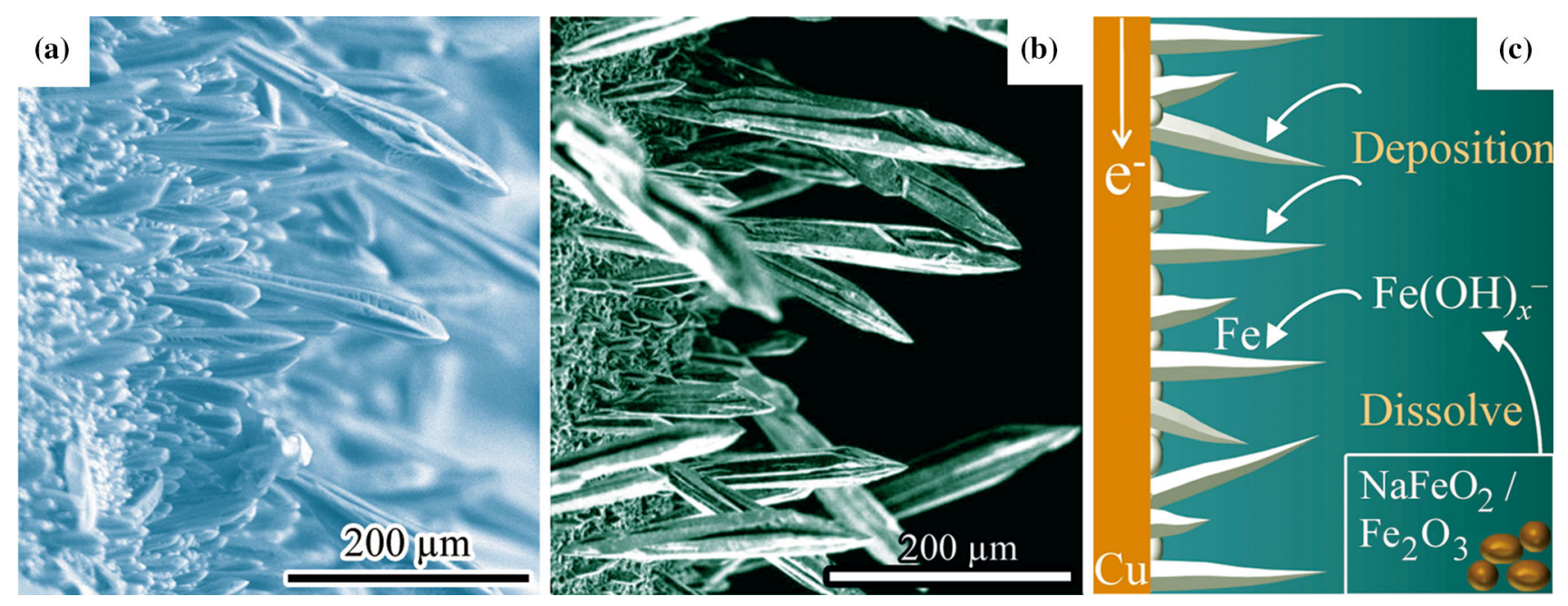

Fig. 15- (a) SEM image and (b) optical microscopic image of the iron particles electrodeposited on copper rod substrate in 60 wt pct aqueous $\mathrm{NaOH}$ solutions saturated with $\mathrm{NaFeO}_{2}(a)$ and $\mathrm{Fe}_{2} \mathrm{O}_{3}(b)$ at $383 \mathrm{~K}\left(110{ }^{\circ} \mathrm{C}\right)$ and $1.7 \mathrm{~V}$ for $4 \mathrm{~h}$, respectively, $(c)$ schematic illustration of the dissolution-electrodeposition route.

60 wt pet aqueous $\mathrm{NaOH}$ solutions at $383 \mathrm{~K}\left(110^{\circ} \mathrm{C}\right)$ and $1.7 \mathrm{~V}$ for 4 hours are shown in Figure 15. Interestingly, the dissolution-electrodeposition-generated iron particles are exactly similar with the electroreductiongenerated iron particles (Figures 13 and 14). This observation further confirms that the dissolution-electrodeposition mechanism ${ }^{[14,18]}$ is the dominated reaction mechanism during the electroreduction process. The dissolved iron species (mainly in the form $\mathrm{Fe}(\mathrm{OH})_{x}^{-}$) would electrodeposit on the copper rod substrate through the electrodeposition Reactions [7] and [8], ${ }^{[15]}$ as shown in Figure 15(c). In addition, Reaction [9] may also coexist in the electrodeposition process based on the thermodynamic analysis. The standard Gibbs free energy changes $\left(\Delta G^{\circ}\right)$ or the theoretical decomposition potentials $\left(E^{\circ}\right)$ for Reactions [4] through [9] have been calculated based on the reported thermodynamic data ${ }^{[48-52]}$ More details about the reaction mechanisms of the electrodeposition of iron from $\mathrm{Fe}_{2} \mathrm{O}_{3}$ and $\mathrm{NaFeO}_{2}$ precursors in aqueous $\mathrm{NaOH}$ solution can be found in our recent work. ${ }^{[56]}$ Therefore, during the electroreduction process in this experiment, $\mathrm{Fe}_{2} \mathrm{O}_{3}$ precursor and the electroreduction-generated $\mathrm{Fe}_{3} \mathrm{O}_{4}$ and/or $\mathrm{NaFeO}_{2}$ intermediates surrounded by aqueous $\mathrm{NaOH}$ solution would dissolve in the nearby electrolyte simultaneously, and then redeposit on the preformed iron to form dendritic crystals in the reaction front area immediately (as schematically shown in Figure 14(b)). Therefore, the direct solid state electroreduction mechanism and the dissolution-electrodeposition mechanism are confirmed to coexist in the reaction area (Figure 14(b)). The dissolution-electrodeposition process may also be partially responsible for the maximum current duration period as shown in Figure 11. The dendritic iron crystals can grow up to approximately 100 to $200 \mu \mathrm{m}$ in length (Figures 13(d) and 14(a)). Actually, the morphology of the electroreduction-generated iron can be controlled by varying the operation conditions. ${ }^{[57]}$
Dissolution reactions:

$$
\begin{aligned}
& \mathrm{Fe}_{3} \mathrm{O}_{4}+4 \mathrm{H}_{2} \mathrm{O}+\mathrm{OH}^{-}+2 \mathrm{e}^{-} \rightarrow \\
& \quad 3 \mathrm{Fe}(\mathrm{OH})_{3}^{-}\left(E_{383 \mathrm{~K}\left[110^{\circ} \mathrm{C}\right]}^{\circ}=1.06 \mathrm{~V}\right) \\
& \mathrm{Fe}_{2} \mathrm{O}_{3}+2 \mathrm{NaOH} \rightarrow 2 \mathrm{NaFeO}_{2} \\
& \quad+\mathrm{H}_{2} \mathrm{O}\left(\Delta G_{383 \mathrm{~K}\left[110^{\circ} \mathrm{C}\right]}^{\circ}=-20.11 \mathrm{~kJ} / \mathrm{mol}\right) \\
& \mathrm{FeO}_{2}^{-}+2 \mathrm{H}_{2} \mathrm{O} \rightarrow \mathrm{Fe}(\mathrm{OH})_{4}^{-}\left(\Delta G_{383 \mathrm{~K}\left[110^{\circ} \mathrm{C}\right]}^{\circ}\right. \\
& <-0.22 \mathrm{~kJ} / \mathrm{mol})
\end{aligned}
$$

Electrodeposition reactions:

$$
\begin{gathered}
\mathrm{Fe}(\mathrm{OH})_{4}^{-}+\mathrm{e}^{-} \rightarrow \mathrm{Fe}(\mathrm{OH})_{3}^{-}+\mathrm{OH}^{-} \\
\left(E^{\circ}{ }_{383 \mathrm{~K}\left[110^{\circ} \mathrm{C}\right]}=\sim 0.75 \mathrm{~V}\right)
\end{gathered}
$$

$$
\begin{gathered}
\mathrm{Fe}(\mathrm{OH})_{3}^{-}+2 \mathrm{e}^{-} \rightarrow \mathrm{Fe}+3 \mathrm{OH}^{-}\left(E^{\circ}{ }_{383 \mathrm{~K}\left[110^{\circ} \mathrm{C}\right]}=\sim 0.73 \mathrm{~V}\right) \\
\mathrm{FeO}_{2}^{-}+2 \mathrm{H}_{2} \mathrm{O}+3 \mathrm{e}^{-} \rightarrow \mathrm{Fe} \\
+4 \mathrm{OH}^{-}\left(E^{\circ} 383 \mathrm{~K}\left[110^{\circ} \mathrm{C}\right]=\sim 0.65 \mathrm{~V}\right)
\end{gathered}
$$

\section{CONCLUSIONS}

Direct electroreduction of spherical $\mathrm{Fe}_{2} \mathrm{O}_{3}$ pellets to Fe crystals in aqueous $\mathrm{NaOH}$ solution has been investigated in this work. The influences of the experimental parameters such as the precursor's sintering temperature, the concentration of aqueous $\mathrm{NaOH}$ solution and electroreduction time on the electroreduction process are studied and discussed. The detailed macro- and microstructures variations during the electroreduction 
process are examined and compared. The optimum operation conditions for the electroreduction process are determined based on the experimental results. In addition, the reaction mechanisms involved in the electroreduction process are discussed. It is found that the porosity of the pellet precursor and the concentration of aqueous $\mathrm{NaOH}$ solution have significant influences on the reduction rate and current efficiency. The electroreduction typically proceeds through the shrinking-core reaction process, which may have implications for understanding the electroreduction of other oxide compounds in molten salts/alkaline solutions. The electroreduction-generated iron particle generally grows in the form of dendritic crystal. The reaction mechanisms are dominated by the dissolution-electrodeposition route, however, the direct solid state electroreduction route also presents in the electrochemical process. The laboratoryscale experiments show that the low temperature electroreduction process can be used to facilely produce dendritic iron crystals directly from iron(III) oxide.

\section{ACKNOWLEDGEMENTS}

The authors thank the National Natural Science Foundation of China (No. 51304132), China National Funds for Distinguished Young Scientists (No. 51225401), the National Basic Research Program of China (No. 2014CB643403), the Science and Technology Commissions of Shanghai Municipality (No. 14JC1491400), and Sichuan Province (No. 2013GZ 0146) for financial support. We also thank the Instrumental Analysis and Research Center of Shanghai University for materials characterization.

\section{REFERENCES}

1. S. Licht and B.H. Wang: Chem. Commun., 2010, vol. 46, pp. 7004-7006.

2. S. Licht, H.J. Wu, Z.H. Zhang, and H. Ayub: Chem. Commun., 2011, vol. 47, pp. 3081-83.

3. D.H. Wang, A.J. Gmitter, and D.R. Sadoway: J. Electrochem. Soc., 2011, vol. 158, pp. E51-54.

4. D.Y. Tang, H.Y. Yin, W. Xiao, H. Zhu, X.H. Mao, and D.H. Wang: J. Electroanal. Chem., 2013, vol. 689, pp. 109-16.

5. H. Kim, J. Paramore, A. Allanore, and D.R. Sadoway: J. Electrochem. Soc., 2011, vol. 158, pp. E101-105.

6. H.P. Gao, X.B. Jin, S.W. Zou, F.Z. Ling, J.J. Peng, Z.Y. Wang, and G.Z. Chen: Electrochim. Acta, 2013, vol. 107, pp. 261-68.

7. S.B. Wang, J.B. Ge, Y.J. Hu, H.M. Zhu, and S.Q. Jiao: Electrochim. Acta, 2013, vol. 87, pp. 148-152.

8. A. Allanore, L. Yin, and D.R. Sadoway: Nature, 2013, vol. 497, pp. 353-357.

9. X.G. Lu, X.L. Zou, C.H. Li, Q.D. Zhong, W.Z. Ding, and Z.F. Zhou: Metall. Mater. Trans. B, 2012, vol. 43B, pp. 503-12.

10. S.L. Wang, G.M. Haarberg, and E. Kvalheim: J. Iron. Steel Res. Int., 2008, vol. 15, pp. 48-51.

11. H.Y. Yin, D.Y. Tang, H. Zhu, Y. Zhang, and D.H. Wang: Electrochem. Commun., 2011, vol. 13, pp. 1521-24.

12. A. Cox and D.J. Fray: Ironmak. Steelmak., 2008, vol. 35, pp. 561-66.

13. A. Cox and D.J. Fray: J. Appl. Electrochem., 2008, vol. 38, pp. 1401-07.

14. B.Y. Yuan, O.E. Kongstein, and G.M. Haarberg: J. Electrochem. Soc., 2009, vol. 156, pp. D64-69.
15. A. Allanore, H. Lavelaine, G. Valentin, J.P. Birat, and F. Lapicque: J. Electrochem. Soc., 2007, vol. 154, pp. E187-193.

16. A. Allanore, H. Lavelaine, G. Valentin, J.P. Birat, P. Delcroix, and F. Lapicque: Electrochim. Acta, 2010, vol. 55, pp. 4007-13.

17. G.M. Li, D.H. Wang, and G.Z. Chen: J. Mater. Sci. Technol., 2009, vol. 25 , pp. 767-71.

18. Z. He, R.V. Gudavarthy, J.A. Koza, and J.A. Switzer: J. Am. Chem. Soc., 2011, vol. 133, pp. 12358-61.

19. X.L. Zou, X.G. Lu, C.H. Li, and B.J. Zhao: Trans. Inst. Min. Metall. C, 2011, vol. 120, pp. 118-124.

20. G.Z. Chen, D.J. Fray, and T.W. Farthing: Nature, 2000, vol. 407, pp. 361-64.

21. W. Xiao and D.H. Wang: Chem. Soc. Rev., 2014, vol. 43, pp. 3215-3228.

22. A.M. Abdelkader, K. Tripuraneni Kilby, A. Cox, and D.J. Fray: Chem. Rev., 2013, vol. 113, pp. 2863-86.

23. K. Jiang, X.H. Hu, M. Ma, D.H. Wang, G.H. Qiu, X.B. Jin, and G.Z. Chen: Angew. Chem. Int. Ed., 2006, vol. 45, pp. 428-432.

24. Q. Xu, L.Q. Deng, Y. Wu, and T. Ma: J. Alloys Compd., 2005, vol. 396, pp. 288-294.

25. X.Y. Yan and D.J. Fray: Metall. Mater. Trans. B, 2002, vol. 33B, pp. $685-693$

26. A. Krishnan, X.G. Lu, and U.B. Pal: Metall. Mater. Trans. B, 2005, vol. 36B, pp. 463-473.

27. D. Hu, W. Xiao, and G.Z. Chen: Metall. Mater. Trans. B, 2013, vol. 44B, pp. 272-282.

28. G.Z. Chen, E. Gordo, and D.J. Fray: Metall. Mater. Trans. B, 2004, vol. 35B, pp. 223-233.

29. X.L. Zou, X.G. Lu, Z.F. Zhou, C.H. Li, and W.Z. Ding: Electrochim. Acta, 2011, vol. 56, pp. 8430-37.

30. X.L. Zou, X.G. Lu, Z.F. Zhou, and C.H. Li: Electrochem. Commun., 2012, vol. 21, pp. 9-13.

31. X.L. Zou, X.G. Lu, Z.F. Zhou, W. Xiao, Q.D. Zhong, C.H. Li, and W.Z. Ding: J. Mater. Chem. A, 2014, vol. 2, pp. 7421-30.

32. R.O. Suzuki, K. Teranuma, and K. Ono: Metall. Mater. Trans. B, 2003, vol. 34B, pp. 287-295.

33. E.T. Turkdogan and J.V. Vinters: Metall. Trans., 1971, vol. 2, pp. $3175-88$

34. A. Pineau, N. Kanari, and I. Gaballah: Thermochim. Acta, 2006, vol. 447, pp. 89-100.

35. L. Barreto, A. Makihira, and K. Riahi: Int. J. Hydrogen Energy, 2003, vol. 28, pp. 267-284.

36. K. Piotrowski, K. Mondal, H. Lorethova, L. Stonawski, T. Szymański, and T. Wiltowski: Int. J. Hydrogen Energy, 2005, vol. 30, pp. 1543-54.

37. K. Jüttner, U. Galla, and H. Schmieder: Electrochim. Acta, 2000, vol. 45 , pp. $2575-94$.

38. D.R. Sadoway: J. Mater. Res., 1995, vol. 10, pp. 487-492.

39. H.Y. Yin, X.H. Mao, D.Y. Tang, W. Xiao, L.R. Xing, H. Zhu, D.H. Wang, and D.R. Sadoway: Energy Environ. Sci., 2013, vol. 6 , pp. $1538-45$.

40. G.M. Haarberg, E. Kvalheim, S. Rolseth, T. Murakami, S. Pietrzyk, and S. Wang: ECS Trans., 2007, vol. 3 (35), pp. 341-45.

41. W. Li, X.B. Jin, F.L. Huang, and G.Z. Chen: Angew. Chem. Int. Ed., 2010, vol. 49, pp. 3203-06.

42. H.L. Chen, Y. Zeng, W. Li, J.J. Peng, X.B. Jin, and G.Z. Chen: Electrochem. Commun., 2013, vol. 26, pp. 33-36.

43. T. Yamashita and P. Hayes: Appl. Surf. Sci., 2008, vol. 254, pp. 2441-49.

44. Y. Deng, D.H. Wang, W. Xiao, X.B. Jin, X.H. Hu, and G.Z. Chen: J. Phys. Chem. B, 2005, vol. 109, pp. 14043-51

45. W. Xiao, X.B. Jin, Y. Deng, D.H. Wang, and G.Z. Chen: Chem. Eur. J., 2007, vol. 13, pp. 604-612.

46. P. Kar and J.W. Evans: Electrochim. Acta, 2008, vol. 53, pp. 526065 .

47. H.D. Jiao, Q.Y. Wang, J.B. Ge, H.B. Sun, and S.Q. Jiao: J. Alloys Compd., 2014, vol. 582, pp. 146-150.

48. I. Barin: in Thermochemical Data of Pure Substances, K. Sora and J. Gardiner, eds., $3^{\text {rd }}$ ed., Wiley-VCH, Weinheim, Germany, 1995.

49. E.L. Shock, D.C. Sassani, M. Willis, and D.A. Sverjensky: Geochim. Cosmochim. Acta, 1997, vol. 61, pp. 907-950.

50. E.L. Shock and H.C. Helgeson: Geochim. Cosmochim. Acta, 1990, vol. 54, pp. 915-945.

51. B. Beverskog and I. Puigdomenech: Corros. Sci., 1996, vol. 38, pp. 2121-35. 
52. I.I. Diakonov, J. Schott, F. Martin, J.C. Harrichourry, and J. Escalier: Geochim. Cosmochim. Acta, 1999, vol. 63, pp. 2247-61.

53. X.L. Zou, X.G. Lu, C.H. Li, and Z.F. Zhou: Electrochim. Acta, 2010, vol. 55, pp. 5173-79.

54. K. Ishikawa, T. Yoshioka, T. Sato, and A. Okuwaki: Hydrometallurgy, 1997, vol. 45, pp. 129-135.
55. G. Picard, D. Oster, and B. Tremillon: J. Chem. Res., 1980, vol. 8, pp. $252-53$.

56. X.L. Zou, S.L. Gu, H.W. Cheng, X.G. Lu, Z.F. Zhou, C.H. Li, and W.Z. Ding: J. Electrochem. Soc., 2015, vol. 162 (1), pp. D49-55.

57. M. Tokushige, O.E. Kongstein, and G.M. Haarberg: ECS Trans., 2013, vol. 50 (52), pp. 103-114. 